\title{
CURRENT BibliogrAPHY: 06 OCT. 2008 - 20 OCT. 2009
}

\author{
Odwin Hoffrichter
}

\author{
Institut für Biologie I, Albert-Ludwigs-Universität Freiburg, Hauptstr. 1, D-79104 Freiburg, Germany \\ Email: odwin.hoffrichter@biologie.uni-freiburg.de
}

In addition to supplements to the last two preceding years the publications of the present year are shown: almost one citation per day, which gives the average speed of publishing with regard to chironomids. The compilation was achieved, as usual, from many sources: databases, tables of contents of journals, references and citations of papers, inspection of many periodicals, lists and pdf's provided by authors (thanks to you!). In particular, publisher issued search alerts proved to be rich in results. As a rule, only printed titles are reported here with the occasional, but obviously increasing, exception of online-only journals (PLoS or BioMed Central journals, e.g.). Titles announced "in press", even with available DOI numbers, are not considered before printing. In general, online information should be retrieved elsewhere; best check the chironomid home page for eventual references regularly, or use individual websites with a host of chironomid-related data. Publications using chironomids as prey or food for animals are not treated comprehensively; in particular, studies with frozen midge larvae only for use to feed experimental animals are totally disregarded.

\section{Supplements to Current Bibliography 2007}

Anjos, A. F. 2007a. Influência das fases hídricas e tipos de substratos artificiais sobre larvas de Chironomidae no trecho superior do rio Paraná. - Diss., Univ. Estad. Maringá.

Anonymus 2007a. Ernst Josef Fittkau turns 80. Ecotropica 13: 80.

Arimoro, F. O., Ikomi, R. B. and Efemuna, E. 2007a. Macroinvertebrate community patterns and diversity in relation to water quality status of River Ase, Niger Delta, Nigeria. - J. Fish. aquat. Sci. 2: 337-344.

Axford, Y. 2007a. Interglacial temperature variability in the high latitude North Atlantic region inferred from subfossil midges, Baffin Island (Arctic Canada) and Iceland. - Ph. D. Diss., Univ. Colo., Boulder.

Chakrabarty, D. 2007a. Comparative utilization of phosphorus from sedimentary and igneous phosphate rock by major biotic components of aquatic ecosystem. - Int. J. envir. Sci. Technol. 4: 43-48.

Corrêa, M. O. D. A. 2007a. Estudo da fauna aquática associada à vegetação do mangue do Rio da Fazenda, Ubatuba (SP) através de experimentos de manipulação. - Diss., Univ. Estad. Paulista, Botucatu. v + 122 pp.

Coulson, S. J. 2007a. Terrestrial and freshwater invertebrate fauna of the High Arctic archipelago of Svalbard. - Zootaxa 1448: 4168.

Fang, J.-F., Lei, X.-L., Cao, T.-H. and Zong, Z.Sh. 2007a. (Influence of Chironomus dorsalis Meigen larva life by environment factor and study of killing the larva) - JingShui Jishu (= Water Purific. Technol.) 26:1-3.

Filippi, M.-A., Heiri, O., Arpenti, E., Angeli, N., Bortiolotti, M., Lotter, A. F. e van der Borg, K. (2005) 2007a. Studio paleolimnologico del Lago Nero di Cornisello (Parco Naturale Adamello-Brenta, Trentino). - Studi trent. Sci. nat., Acta geol. 82: 261-278.

Filippi, M.-A., Heiri, O., Arpenti, E., Angeli, N., Bortiolotti, M., Lotter, A. F. e van der Borg, K. (2005) 2007b. Evoluzione paleoambientale dal Tardoglaciale a oggi ricostruita attraverso lo studio dei sedimenti del Lago di Lavarone (Altopiano di Folgaria e Lavarone, Trentino). - Studi trent. Sci. nat., Acta geol. 82: 279-298.

Giłka, W., Kłonowska-Olejnik, M. and Godunko, R. J. 2007a. On the biology of Symbiocladius rhithrogenae (Zavřel, 1924) (Diptera: Chironomidae) from the Chornohora Mts., Ukraine. - Pol. J. Ent. 76: 285-291.

Gritzalis, K. C., Karaouzas, I. and Skoulikidis, N. 2007a. Assessing the ecological quality of running waters of Thrace region (NE Greece) by the use of macroinvertebrate indicators. Fresenius envir. Bull. 15: 1182-1188.

Guo, Y. H. and Wang, X. H. 2007a. Zavrelia bragremla [for: bragremia] sp. nov. from China (Diptera, Hironomidae [sic!], Tanytarsini). - Dong Wu Fen Lei Xue Bao (= Acta zootaxon. sin.) 32: 318-320.

Guo, Y. H. and Wang, X. H. 2007b. Stempelinella depilisa sp. nov. from China (Diptera, Chironomidae, Tanytarsini). - Dong 
Wu Fen Lei Xue Bao (= Acta zootaxon. sin.) 32: 321-323.

Guo, Y. H. and Wang, X. H. 2007c. (A new combination Cladotanytarsus gracilistylus (Chaudhuri \& Datta, 1992) (Diptera: Chironomidae) from China.) - Kun Chong Fen Lei Xue Bao (= Entomotaxonomia) 29: 297300.

Heiri, O., Filippi, M.-L. and Lotter, A. F. (2005) 2007a. Lateglacial summer temperature in the Trentino area (Northern Italy) as reconstructed by fossil chironomid assemblages in Lago di Lavarone (1100 m a.s.l.) - Studi trent. Sci. nat., Acta geol. 82: 299-308.

Int Panis, L. 2007a. Genetische variatie in populaties van Chironomus nuditarsis Keyl (Diptera, Chironomidae); implicaties voor biodiversiteit. (Genetic variation in populations of Chironomus nuditarsis Keyl (Diptera, Chironomidae); implications for biodiversity.) - In: Congr. Watersysteemkennis 2006-2007, Aquatische Biodiversiteit. Water 2007/IMS/P/0089: 3 pp.

Janke, H. and Trivinho-Strixino, S. 2007a. Colonization of leaf litter by aquatic macroinvertebrates: a study in a low order tropical stream. - Acta limnol. bras. 19: 109115.

Karaouzas, I., Gritzalis, K. C. and Skoulikidis, N. 2007a. Land use effects on macroinvertebrate assemblages and stream quality along an agricultural river basin. - Fresenius envir. Bull. 16: 645-653.

Kerckhof, F., Haelters, J. and Gollasch, S. 2007a. Alien species in the marine and brackish ecosystem: the situation in Belgian waters. Aquat. Invasions 2: 243-257.

Lei, P., Liu, L.-j., Zhang, J.-s. and Chen, Y.-q. 2007a. (A study on microbiological control on chironomid pollution in city water supply) Wei Sheng $W u$ Xue Tong Bao (= Microbiology) 34: 296-299.

Lin, H.-b., Song, Zh.-hui and Wang, F.-f. 2007a. (Toxic effect of triphenyltin on Chironomus plumosus larve, Galba pervia and Tubifex tubifex) - Qingdao Keji Daxue Xuebao (= J. Qingdao Univ. Sci. Technol., nat. Sci. Edn) 28: 386-389, 393.

Liu, L.-j., Zhang, J.-s., Chen, Y.-q. and Zhou, L. 2007a (Growth, reproduction regularity and prediction of chironomid midge in water supply system) - Gong Shui Ji Shu (= Water Technol.) 1, 2:10-13.
Michailova, P., Sella, G. and Petrova, N. 2007a. Effect of heavy metals on the genome of a model insect group (Diptera, Chironomidae). In: Evolyutsiya i ekologiya 2007, Proc., pp. 36-44. Sofia.

Mo, W.-j. 2007a. (Discussion on inactivation methods of Chironomus larva in water treatment process) - Gongye Anquan $\mathrm{Yu}$ Huanbao (= Ind. Saf. envir. Protect.) 33(5): 21-22.

Moubayed-Breil, J. et Dia, A. (2006) 2007a. Espèces de Chironomes nouvelles pour la faune du Liban et du Proche-Orient [Diptera, Chironomidae]. - Ephemera 8: 101-107.

Moubayed-Breil, J., Lounaci, A. and LounaciDaoudi, D. (2006) 2007a. Non-biting midges from Algeria, North Africa [Diptera, Chironomidae]. - Ephemera 8: 93-99.

Murray, D. A. and Baars, J. R. 2007a. Parapsectra uliginosa Reiss, 1969 (Diptera, Chironomidae) new to Ireland and association of exuviae of Procladius Pe1 (sensu Langton) with $P$. simplicistilus Freeman, 1948. Dipterists Dig. Sec. Ser. 13: 166-168.

Niitsuma, H. 2007b. Rheopelopia and two new genera of Tanypodinae (Diptera, Chironomidae) from Japan. - Jap. J. syst. Ent. 13: 99-116.

Pan, J., Zhang, J.-s. and Sun, T.-h. 2007a. (Control of Chironomidae larvae in water treatment by Bacillus thuringiensis var. israelensis de Bariac) - Sheyang Shifan Daxue Xuebao-Zirankexue Ban (= J. Shenyang Norm. Univ. (Nat. Sci.)) 25: 80-82.

Perkovsky, E. E., Rasnitsyn, A. P., Vlaskin, A. P. and Taraschuk, M. V. 2007a. A comparative analysis of the Baltic and Rovno amber arthropod faunas: representative samples. - In: Brothers, D. J. and Mostovski, M. B. (eds): Congr. Proc. Fossils X 3, Pretoria, South Africa, 7-11 February 2005. Natal Mus., Pietermaritzburg. Afr. Invertebrates 48: 229245.

Punti Casadellà, T. 2007a. Ecologia de les comunitats de quironòmids en rius mediterranis de referència. (Ecology of Chironomidae communities in Mediterranean reference streams.) - Tes. doct., Univ. Barcelona. $\mathrm{xx}+151 \mathrm{pp}$.

Resende, D. L. M. C. e Takeda, A. M. 2007a. Larvas de Chironomidae (Diptera) em três reservatórios do Estado do Paraná, Brasil. Revta bras. Zoociênc. 9: 167-176. 
Rieradevall, M., Chaves, M. L. and Prat, N. 2007a. High altitude Chironomidae (Diptera) of Serra da Estrela (Portugal): additions to the Portuguese and Iberian Peninsula fauna. Graellsia 63: 273-278.

Rodríguez-Barrios, J., Ospina-Torres, R., Gutiérrez, J. D. y Ovalle, H. 2007a. Densidad y biomasa de macroinvertebrados acuáticos derivantes en una quebrada tropical de montaña (Bogotá, Colombia). - Caldasia 29: 397-412.

Rosin, G. C. 2007a. Larvas de Chironomidae em substratos artificiais: comparações e padrões de colonização em três rios de planície de inundação do alto rio Paraná, Brasil. - Mast. Thes., Univ. Estad. Maringá.

Shitikov, V. K., Zincheko, T. D. i Golovatyuk, L. V. 2007a. Struktura bazy dannykh i algoritmy obrabotki informatsii. (Structure of data base and algorithm of information processing.) - In: Bukharin, O. V. i Rozenberg, G. S. (eds.): Bioindikatsiya ekologicheskogo sostoyania ravninnykh rek. (Bioindication of ecological state of lowland rivers), pp. 86-103. Nauka, Moskva.

Sun, X.-B., Cui, F.-Y., Zhang, J.-S., Xu, F. and Liu, L.-J. 2007a. Inactivation of chironomid larvae with chlorine dioxide. - J. hazard. Mater. 142: 348-353.

Taşdemir, A., Ustaoğlu, M. R. ve Balık, S. 2007a. Akgöl ve Gebekirse Gölü'nün (Selçuk-İzmir) Chironomidae (Diptera-Arthropoda) Faunası. (Chironomidae (Diptera - Arthropoda) fauna of Akgöl and Lake Gebekirse (Selçuk-İzmir). - Ulusal Su Günleri 2007 Sempozyumu, 16-18 Mayıs 2007, Antalya, Türk Sucul Yaşam Dergisi, pp. 224-228.

Veltz, I., Azar, D. and Nel, A. 2007a. New chironomid flies in Early Cretaceous Lebanese amber (Diptera: Chironomidae). In: Brothers, D. J. and Mostovski, M. B. (eds.): Congr. Proc. Fossils X 3, Pretoria, South Africa, 7-11 February 2005. Natal Mus., Pietermaritzburg, pp. 169-191. [also published as: Afr. Invert. 48: 169-191.]

Vidinova, Y. N., Yaneva, I. Y., Tyufekchieva, V. G. and Zadneprovski, B. E. 2007a. Composition and abundance of macroinvertebrate communities in the Arda River (South Bulgaria) in relation to some ecological factors. - Acta zool. bulg. 59: 309324.

Walker, I. 2007a. The macrofauna associated with Eichhornia crassipes roots during the phase of declining eutrophication in the Balbina Reservoir (Presidente Figueiredo, Amazonas, Brasil). - Acta limnol. bras. 19: 473-483.

Werner, D., Reusch, W. and Pont, A. C. 2007a. Dicranomyia didyma (Meigen) (Diptera: Limoniidae) as a larval predator of Chironomidae and Simuliidae and as adult prey of Muscidae (Diptera), with notes on the developmental cycle. - Entomologist's mon. Mag. 143: 101-111.

Würdig, N. L., Cenzano, C. S. S. and Motta Marques, D. 2007a. Macroinvertebrate communities structure in different environments of the Taim Hydrological System in the state of Rio Grande do Sul, Brazil. - Acta limnol. bras. 19: 427-438.

Zhang, Ch.-h., Zhu, Sh.-q., Chen, Y., Qi, Ch.-d., Ji, Y., Zhu, Y.-j. and Zhao, J. 2007a. (Analysis of water quality in Miyun reservoir) - Huanjing Kexue Yu Jishu (= Envir. Sci. Technol.) 2007(z1): 63-64, 96.

Zhang, R.-L. and Wang, X.-H. 2007a. A new species of subgenus Polypedilum ( s. str.) Kieffer (Diptera: Chironomidae) from China. - Entomotaxonomia 29: 293-296.

Zhang, R.-L. and Wang, X.-H. 2007b. Two new species of Polypedilum (Tripodura) Townes from oriental China (Diptera, Chironomidae). - Dong Wu Fen Lei Xue Bao (= Acta zootaxon. sin.) 32: 787-791.

Zhu, D., Su, H.-y. and Zheng, Y.-ch. 2007a. (A review on infesting and bio-prevention of chironomus larva pollution in municipal water system) - Chuxiong Shifan Xueyuan Xuebao (= J. Chuxiong Normal Univ.) 22, 6: 43-47.

Zhu, G.-q. 2007a (A study on prevention of chironomid larvae pollution of secondary water supply) - Guangdong Keji (= Guangdong Sc. Technol.) 164: 36-37.

Zinchenko, T. D. i Moller Pilot, Kh. K. M. 2007a. Indikatsionnaya rol' ekzuviev kukolok khironomid pri otsenke kachestva vodnykh ekosistem ravninnykh rek. (Indicator role of chironomid pupal exuviae in evaluation of the quality of aquatic ecosystems of lowland rivers.) - In: Bukharin, O. V. i Rozenberg, G. S. (eds.): Bioindikatsiya ekologicheskogo sostoyania ravninnykh rek. (Bioindication of ecological state of lowland rivers), pp. 237242. Nauka, Moskva.

Zinchenko, T. D. i Rozenberg, G. S. 2007a. Otsenka kachestva bioindikatorov. 
(Evaluation of the qualiyt of bioindicators.) In: Bukharin, O. V. i Rozenberg, G. S. (eds.): Bioindikatsiya ekologicheskogo sostoyania ravninnykh rek. (Bioindication of ecological state of lowland rivers), pp. 370-380. Nauka, Moskva.

Zinchenko, T. D., Golovatyuk, L. V. i Zagorskaya, E. P. 2007a. Strukturnaya organizatsiya soobshchestv makrozoobentosa ravninnykh rek pri antropogennom vozdeistvii. (Structural organization of macrozoobenthos communities of lowland rivers under anthropogenic influence. - In: Bukharin, O. V. i Rozenberg, G. S. (eds.): Bioindikatsiya ekologicheskogo sostoyania ravninnykh rek. (Bioindication of ecological state of lowland rivers), pp. 217-233. Nauka, Moskva.

Zinchenko, T. D., Sharyi, P. A., Sharaya, L. S., Shitikov, V. K. i Abrosimova, E. V. 2007a. Znachenie rel'efa $\mathrm{V}$ otsenke gidrobiologichesdkogo sostoyiya malykh rek. (Importance of the relief in evaluation of the hydrobiological state of small rivers.) - In: Bukharin, O. V. i Rozenberg, G. S. (eds.): Bioindikatsiya ekologicheskogo sostoyania ravninnykh rek.

\section{Supplements to Current Bibliography 2008}

Al-Saffar, M. A. T. 2008a. An invitation for stopping cholera in Iraq before its outbreak. Nature Iraq Paper 2008: 5 pp. Sulaimani, Kurdistan, Iraq.

Amirkolaie, A. K. 2008a. Diet composition of sturgeon fry (Acipenser persicus) reared in fertilized earthen ponds. - Aquacult. Res. 40: 112-117.

Andersen, T., Mendes. H. F. and de Pinho, L. C. 2008a. Two new species of Stenochironomus KIEFFER, 1919 from the Brazilian Atlantic Rainforest (Diptera: Chironomidae). - Studia dipterol. 14: 263-269.

Armengol, X., Anton-Pardo, M., Atienzar, F., Echevarrias, J. L. and Barba, E. 2008a. Limnological variables relevant to the presence of the endangered white-headed duck in southeastern Spanish wetlands during a dry period. - Acta zool. Acad. Scient. hung. 54, Suppl. 1: 45-60.

Béchard, K. M., Gillis, P. L. and Wood, C. M. 2008a. Trophic transfer of Cd from larval chironomids (Chironomus riparius) exposed via sediment or waterborne routes, to zebrafish (Danio rerio): Tissue-specific and subcellular comparisons. - Aquat. Toxic. 90: 310-321.

Beketov, M. A., Schäfer, R. B., Marwitz, A., Paschke, A. and Liess, M. 2008a. Long-term stream invertebrate community alterations induced by the insecticide thiacloprid: Effect concentrations and recovery dynamics. - Sci. tot. Envir. 405: 96-108.

Benbow, M. E. 2008a. Role of larval sexual dimorphism, biased sex ratios, and habitat on the energetics of a tropical chironomid. Envir. Ent. 37: 1162-1173.

Borderelle, A.-L., Gilmette, C., Lovy, C., Gerdeaux, D. and Verneaux, V. 2008a. Macroinvertebrate $\delta^{13} \mathrm{C}$ variability analysis for the assessment of lake trophic functioning. Fundam. appl. Limnol. 172: 289-300.

Berezina, N. A. 2008a. Spatial distribution of macrofauna in a littoral zone with drifting macroalgae in the Neva estuary. - Eston. J. Ecol. 57: 198-213.

Botelho, S. C., Tyagi, A., Hessle, V., Östlund Farrants, A. K. and Visa, N. 2008a. The association of Brahma with the Balbiani ring 1 gene of Chironomus tentans studied by immunoelectron microscopy and chromatin immunoprecipitation. - Insect molec. Biol. 17: 505-513.

Brodin, Y., Lundström, J. O. and Paasivirta, L. 2008a. Tavastia yggdrasilia, a new orthoclad midge (Diptera: Chironomidae) from Europe. - Aquat. Insects 30: 261-267.

Broza, M., Gancz, H. and Kashi, Y. 2008a. The association between non-biting midges and Vibrio cholerae. - Envir. Microbiol. 10: 31933200.

Chen, Ch.-x. and Lu, P. 2008a. (Prevention of chironomid and its larvae in waterworks using advanced treatment) - Zhongguo Jishui Panshui (= China Water and Wastewater) 24, 6: 95-98.

Chen, J. H., Chen, F. H., Zhang, E. L., and Zhou, A. F. 2008a. (A preliminary study on chironomid-based salinity reconstruction for Sugan Lake in the last millennium). Quatern. Sci. 28: 338-344.

Cheng, M. and Wang, X. 2008a. New species of Clinotanypus Kieffer, 1913 (Chironomidae: Tanypodinae) from China. - Zootaxa 1944: 53-65.

Chételat, J., Amyot, M., Cloutier, L. and Poulain, A. 2008a. Metamorphosis in chironomids, 
more than mercury supply, controls methylmercury transfer to fish in high Arctic lakes. - Envir. Sci. Technol. 42: 9110-9115.

Clayton, J. A. and Westbrook, C. J. 2008a. The effect of the Grand Ditch on the abundance of benthic invertebrates in the Colorado River, Rocky Mountain National Park. - River Res. Applics 24: 975-987.

Copp, G. H., Kováč, V., Zweimüller, I., Dias, A., Nascimento, M. and Balážová; M. 2008a. Preliminary study of dietary interactions between invading Ponto-Caspian gobies and some native fish species in the River Danube near Bratislava (Slovakia). - Aquat. Invasions 3: 193-200.

Corbi, J. J. and Trivinho-Strixino, S. 2008a. Relationship between sugar cane cultivation and stream macroinvertebrate communities. Braz. Archs Biol. Tech. 51: 569-579.

Cremona, F., Planas, D. and Lucotte, M. 2008a. Assessing the importance of macroinvertebrate trophic dead ends in the lower transfer of methylmercury in littoral food webs. - Can. J. Fish. aquat. Sci. 65: 2043-2052.

Cui, Y. and Wang, H. 2008a. (Ecology of macrozoobenthic communities in two plateau lakes of Southwest China.) - Chin. J. Oceanol. Limnol. 26: 345-352.

Deak, Cs., Gor, D. and Lakatos, Gy. 2008a. Phytophilous macrofauna assessments in an important aquatic bird area: the Kis-Balaton protection system. - Acta zool. Acad. Scient. hung. 54, Suppl. 1: 75-83.

De Haas, E. M. and Kraak, M. H. S. 2008a. Species-specific responses of two benthic invertebrates explain their distribution along environmental gradients in freshwater habitats. - Sci. tot. Envir. 406: 430-435.

De Jonge, M., van de Vijver, B., Blust, R. and Bervoets, L. 2008a. Responses of aquatic organisms to metal pollution in a lowland river in Flanders: A comparison of diatoms and macroinvertebrates. - Sci. tot. Envir. 407: 615-629.

De Lange, H. J., Griethuysen, C. van and Koelmans, A. A. 2008a. Sampling method, storage and pretreatment of sediment affect AVS concentrations with consequences for bioassay responses. - Envir. Pollut. 151: 243251.

De Lange, H. J., Peeters, E. T. H. M., Harmsen, J., Maas, H. and De Jonge, J. 2008a. Seasonal variation of total and biochemically available concentrations of PAHs in a floodplain lake sediment has no effect on the benthic invertebrate community. - Chemosphere 75: 319-326.

De Sousa, S., Pinel-Alloul, B. and Cattaneo, A. 2008a. Response of littoral macroinvertebrate communities on rocks and sediments to lake residential development. - Can. J. Fish. aquat. Sci. 65: 1206-1216.

Donato, M., Massaferro, J. and Brooks, S. J. 2008a. Chironomid (Chironomidae: Diptera) checklist from Nahuel Huapi National Park, Patagonia, Argentina. - Revta Soc. ent. argent. 67: 163-170.

Dussault, E. B., Balakrishnan, V. K., Solomon, K. R. and Sibley, P. K. 2008a. Chronic toxicity of the synthetic hormone $17 \alpha$-ethinylestradiol to Chironomus tentans and Hyalella azteca. Envir. Toxic. Chem. 27: 2521-2529.

Eagles-Smith, C. A., Suchanek, T. H., Colwell, A. E. and Anderson, N. L. 2008a. Mercury trophic transfer in a eutrophic lake: the importance of habitat-specific foraging. Ecol. Applics 18, spec. Issue: A196-A212.

Eggermont, H., Kennedy, D., Hasiotis, S. T., Verschuren, D. and Cohen, A. 2008a. Distribution of living larval Chironomidae (Insecta: Diptera) along a depth transect at Kigoma Bay, Lake Tanganyika: implications for palaeoenvironmental reconstruction. - Afr. Ent. 16: 162-184.

Eggermont, H., Verschuren, D., Fagot, M., Rumes, B., Van Bocxlaer, B. and Kröpelin, S. 2008a. Aquatic community response in a groundwater-fed desert lake to Holocene desiccation of the Sahara. - Quatern. Sci. Rev. 27: 2411-2425.

Fernández, H. R., Romero, F. and Domínguez, E. 2009a. Intermountain basins use in subtropical regions and their influences on benthic fauna. - River Res. Applics 25: 181-193.

Filippi, M. L., Angeli, N., Marziali, L., Matouk, A. H. I., Bertuzzi, E., Lencioni, V. and Cantonati, M. 2008a. Paleolimnological techniques applied to spring habitats: Challenges and limits as highlighted by the CRENODAT project (southeastern Alps, Italy). - Verh. int. Verein. Limnol. 30: 329332.

Fleissner, Ge., Fleissner, Gu., Kaiser, T., Schuchardt, K. and Neumann, D. 2008a. Multiple extraretinal photoreceptors in the 
intertidal midge Clunio marinus. - In: Warrant, E. and Nilsson, D. E. (eds.): $2^{\text {nd }}$ Int. Conf. Invert. Vision, p. 174. Lund Univ.

Fleissner, Gu., Fleissner, Ge., Schuchardt, K. and Neumann, D. 2008a. Larval ocelli as a putative moonlight receptor. - In: Warrant, E. and Nilsson, D. E. (eds.): $2^{\text {nd }}$ Int. Conf. Invert. Vision, p. 62. Lund Univ.

Fu, Y. and Wang, X.-H. 2008a. A new species of Paratrichocladius Santos Abreu (Diptera: Chironomidae) from China. - Si Chuan Dong Wu (= Sichuan J. Zool.] 27: 728-730.

Fusari, L. M., Roque, F. O. and Hamada, N. 2008a. Sponge-dwelling chironomids in the Upper Paraná River (Brazil): Little known but potentially threatened species. - Neotrop. Ent. 37: 522-527.

Gardarsson, A., Petersen, A. and Einarsson, A. 2008a. Population limitation in dabbling ducks at Myvatn, Iceland. - Acta zool. Acad. Scient. hung. 54, Suppl. 1: 131-143.

Gavrilă, L., Burlibaşa, L., Uşurelu, M. D., Radu, I., Magdalena, L. M., Ardelean, A. and Cărăbaş, M. 2008a. Chromosomal rearrangements in Chironomus sp. as genosensors for monitoring environmental pollution. - Rom. biotechnol. Lett. 13: 39623969.

Gergs, R. and Rothhaupt, K.-O. 2008a. Feeding rates, assimilation efficiencies and growth of two amphipod species on biodeposited material from zebra mussels. - Freshwat. Biol. 53: 2494-2503.

Giłka, W. 2008a. An intraspecific morphological variability of Zavrelia pentatoma KIEFFER (Diptera: Chironomidae). - Dipteron 24: 1115.

Golygina, V. V. and Kiknadze, I. I. 2008a. The revision of chromosome I (AB) mapping in Chironomus plumosus group (Diptera: Chironomidae). - Comp. Cytogenet. 2: 37-55.

Goudie, R. I. and Gilliland, S. G. 2008a. Aspects of distribution and ecology of harlequin ducks on the Torrent River, Newfoundland. Waterbirds 31, spec. Issue 2: 92-103.

Grimaldi, D. A. and Triplehorn, D. M. 2008a. Insects from the Upper Miocene Grubstake Formation of Alaska. - Am. Mus. Novit. 3612: 1-19.

Gunderina, L. I., Kiknadze, I. I., Mikhailova, P. V. i Krastanov, B. D. 2008a. Izmenchivost' i divergentsiya genomnykh DNK Chironomus plumosus L. i Chironomuis balatonicus Dévai, Wülker et Scholl (Diptera, Chironomidae) v prirodnykh populyatsiyakh Rossii i Bolgarii. (Variation and divergence of genomic DNA in Chironomus plumosus L. and Chironomus balatonicus Dévai, Wülker et Scholl (Diptera, Chironomidae) of natural populations in Russia and Bulgaria.) - Evraziat. ent. Zh. (= Euroas. ent. J.) 7: 167-174.

Gyllström, M., Lakowitz, T., Brönmark, C. and Hansson, L.-A. 2008a. Bioturbation as driver of zooplankton recruitment, biodiversity and community composition in aquatic ecosystems. - Ecosystems 11: 1120-1132.

Hirabayashi, K., Tanizaki, S. and Yamamoto M. 2008a. Chironomid (Diptera, Chironomidae) fauna in a filtration plant in Japan. - In: Robinson, W. H. and Bajomi, D. (eds.): Proc. $6^{\text {th }}$ Int. Conf. Urban Pests: 187-192. OOK-Pr. Kft., Veszprém.

Hoffmann, A. A., Reynolds, K. T., Nash, M. A. and Weeks, A. R. 2008a. A high incidence of parthenogenesis in agricultural pests. - Proc. R. Soc. B 275: 2473-2481.

Holmes, N. 2008a. Validation of chironomidinferred temperature reconstructions in Iceland: the potential for reconstructing quantitative changes in Holocene climate. Geogr. helv. 63: 4-14.

Hughes, S. J., Ferreira, T. and Cortes, R. V. 2008a. Hierarchical spatial patterns and drivers of change in benthic macroinvertebrate communities in an intermittent Mediterranean river. - Aquat. Conserv. mar. Freshwat. Ecosyst. 18: 742-760.

Ilkova, J., Michailova, P., Petrova, N., Sella, G., Hankeln, T. and Schmidt, E. 2008a. Repetitive DNA localization in two homosequential species of the genus Chironomus Kieffer (Diptera: Chironomidae) and their genome reaction to anthropogenic factors. - Acta zool. bulg., Suppl. 2: 41-48.

Inoue, E., Kimura, G. and Hirabayashi, K. 2008a. Chironomids (Diptera: Chironomidae) attracted to vending machines in the middle reach of the Shinano River, Japan. - In: Robinson, W. H. and Bajomi, D. (eds.): Proc. $6^{\text {th }}$ Int. Conf. Urban Pests: 177-185. OOK-Pr. Kft., Veszprém.

Jacobsen, D. and Marín, R. 2008a. Bolivian Altiplano streams with low richness of macroinvertebrates and large diel fluctuations in temperature and dissolved oxygen. - Aquat. Ecol. 42: 643-656. 
Jacobsen, R. E. 2008a. A key to the pupal exuviae of the midges (Diptera: Chironomidae) of Everglades National Park, Florida. - U. S. Geol. Surv. Scient. Invest. Rep. 2008-5082: 119 pp.

Janas, U. and Barańska, A. 2008a. What is the diet of Palaemon elegans Rathke, 1837 (Crustacea, Decapoda), a non-indigenous species in the Gulf of Gdańsk (southern Baltic Sea)? - Oceanologia 50: 221-237.

Jarzembowski, E. A., Azar, D. and Nel, A. 2008a. A new chironomid (Insecta: Diptera) from Wealden amber (Lower Cretaceous) of the Isle of Wight (UK). - Geol. Acta 6: 285-291.

Javanshir, A., Shapoori, M. and Jamili, S. 2008a. Diversity of benthic invertebrate fauna and secondary production in southern Caspian Sea basin, case study on Tajan River estuary. - $J$. Fish. aquat. Sci. 3: 353-365.

Jiang, J., Wen, F.-n., Su, H.-w., Li, X.-y., He, P. and Yan, Y.-j. 2008a. (Population dynamics, annual production, and trophic basis of dominant chironomids in Tanqigou Stream.) Sheng Tai Xue Za Zhi (= Chin. J. Ecol.) 27: 1503-1509.

Johnson, A. A. and Kleve, M. G. 2008a. A new species of mermithid (Nematoda) in chironomids eclosing from a northern Minnesota bog. - J. Parasit. 94: 1342-1345.

Johnson, J. H., McKenna Jr., J. E., Nack, C. C. and Chalupnicki, M. A. 2008a. Diel diet composition and feeding activity of round goby in the nearshore region of Lake Ontario. - J. Freshwat. Ecol. 23: 607-612.

Jorcin, A. and Nogueira, M. G. 2008a. Benthic macroinvertebrates in the Paranapanema reservoir cascade (southeast Brazil). - Braz. J. Biol. 68, 4, Suppl.: 1013-1024.

Jung, S. W., Nguyen, V. V., Nguyen, Q. H. and Bae, Y. J. 2008a. Aquatic insect faunas and communities of a mountain stream in Sapa Highland, northern Vietnam. - Limnology 9: 219-229.

Kibichii, S., Shivoga, W. A., Muchiri, M., Enanga, E. and Miller, S. N. 2008a. Seasonality in water quality and its influence on the abundance and distribution of phytoplankton and chironomid larvae in Lake Nakuru, Kenya. - Verh. int. Verein. Limnol. 30, 3: 333-338.

Kiknadze, I. I., Golygina, V. V., Broshkov, A. D., Gunderina, L. I. and Istomina, A. G. 2008a. Mystery of Chironomus dorsalis Meigen karyotype (Diptera: Chironomidae). - Comp. Cytogenet. 2: 21-35.

Koščo, J., Manko, P., Miklisová, D., Košuthová, L. 2008a. Feeding ecology of invasive Perccottus glenii (Perciformes, Odontobutidae) in Slovakia. - Czech J. Anim. Sci. 53: 479-486.

Krakowiak, P. J.and Pennuto, C. M. 2008a. Fish and macroinvertebrate communities in tributary streams of eastern Lake Erie with and without round gobies (Neogobius melanostomus, Pallas 1814). - J. Gt Lakes Res. 34: 675-689.

Krasheninnikov, A. B. i Makarchenko, E. A. 2008a. Prosmittia verae sp. n. - novyi vid komarov-zvontsov (Diptera: Chironomidae: Orthocladiinae) iz okrestnostei Sochi (Severnyi Kavkaz). (Prosmittia verae sp. n. a new chironomid species (Diptera: Chironomidae: Orthocladiinae) from the environs of Sochi Town (the Northern Caucasus). - Kavkaz. ent. Byul. 4: 359-361.

Krastanov, B. D. and Michailova, P. V. 2008a. Cytotaxonomic characteristic of four species of plumosus group in genus Chironomus Meigen 1803 (Diptera: Chironomidae) from Bulgaria and Poland. - Acta zool. bulg., Suppl. 2: 49-60.

Krivosheina, M. G. 2008a. O pitanii nasekomykh tsianobakteriyami. (On insect feeding on cyanobacteria.) - Paleont. Zh. 2008, 6: 26-29. [also published in: Paleont. J. 42: 596-599.]

Landeiro, V. L., Hamada, N. and Melo, A. S. 2008a. Responses of aquatic invertebrate assemblages and leaf breakdown to macroconsumer exclusion in Amazonian "terra firme" streams. - Fundam. appl. Limnol. 172: 49-58.

Larsen, S., Vaughan, I. P. and Ormerod, S. J. 2008a. Scale-dependent effects of fine sediments on temperate headwater invertebrates. - Freshwat. Biol. 54: 203-219.

Lerner, A., Meltser, N., Sapir, N., Erlick, C., Shashar, N. and Broza, M. 2008a. Reflected polarization guides chironomid females to oviposition sites. - J. exp. Biol. 211: 35363543.

Li, A. O. Y. and Dudgeon, D. 2008a. Food resources of shredders and other benthic macroinvertebrates in relation to shading conditions in tropical Hong Kong streams. Freshwat. Biol. 53: 2011-2025. 
Lods-Crozet, B., Reymond, O. et Strawczynski, A. 2008a. Evaluation de l'état écologique de deux lacs sub-alpins suisses (canton de Vaud). - Bull. Soc. vaud. Sci. nat. 91: 157-173.

Love, J. W., Taylor, C. M. and Warren Jr., M. P. 2008a. Effects of summer drought on fish and macroinvertebrate assemblage properties in upland Ouachita Mountain streams, USA. Am. Midl. Nat. 160: 265-277.

Makarchenko, E. A. and Makarchenko, M. A. 2008a. Doithrix doriceni sp. n. (Diptera, Chironomidae, Orthocladiinae) from South Primorye of the Russian Far East. - Evraz. ent. Zh. (= Euroas. ent. J.) 7: 68-70.

Makarchenko, E. A. and Makarchenko, M. A. 2008b. The first record of Platysmittia Sæther (Diptera, Chironomidae, Orthocladiinae) in Palaearctic region. - Evraz. ent. Zh. (= Euroas. ent. J.) 7: 177-179.

Makarchenko, E. A. and Makarchenko, M. A. 2008c. Dopolneniya i utochneniya $k$ faune khironomid podsemeistva Orthocladiinae (Diptera, Chironmidae) rossiiskogo Dal'nego Vostoka. (Additions and corrections to the Orthocladiinae (Diptera, Chironomidae) fauna of the Russian Far East.) - In: Chteniya pamyati Vladimira Yakovlevicha Levanidova (Vladimir Ya. Levanidov's Biennial Memorial Meetings) 4: 172-186. Dal'nauka, Vladivostok.

Makarchenko, E. A. and Makarchenko, M. A. 2008d. Novye nakhodki khironomid (Diptera, Chironomidae) na Dal'nego Vostoke i sopredel'nykh territoriyakh. V. Podsemeistvo Orthocladiinae. (New findings of chironomids (Diptera, Chironomidae) in Far East and bordering territories. V. Subfamily Orthocladiinae.) - In: Chteniya pamyati Vladimira Yakovlevicha Levanidova (Vladimir Ya. Levanidov's Biennial Memorial Meetings) 4: 187-195. Dal'nauka, Vladivostok.

Makarchenko, E. A. and Makarchenko, M. A. 2008e. Review of the genus Pseudosmittia Edwards (Diptera: Chironomidae: Orthocladiinae) from the Russian Far East (Diptera: Chironomidae: Orthocladiinae). Russ. ent. J. 17: 215-226.

Makarchenko, E. A. and Yavorskaya, N. M. 2008a. Monodiamesa kamora sp. n. (Diptera, Chironomidae, Prodiamesinae) from the Amur River basin. - Evraz. ent. Zh. (= Euroas. ent. J.) 7: 175-176.

Makarchenko, E. A., Wu, J. and Wang, X. 2008a. Two new species of chironomids (Diptera:
Chironomidae) from China. - Russ. ent. J. 17: 321-323.

Marques, T. S., Ferronato, B. O., Guardia, I., Longo, A. L. B., Trivinho-Strixino, S., Bertoluci, J. e Verdade, L. M. 2008a. Primeiro registro de larvas de Chironomus inquinatus Correia, Trivinho-Strixino \& Michailova (Diptera, Chironomidae) vivendo no casco do cágado Phrynops geoffroanus Schweigger (Testudines, Chelidae) na região Neotropical. - Biota neotrop. 8: 201-203.

Martínez-Guitarte, J. L., Díez, J. L. and Morcillo, G. 2008a.Transcription and activation under environmental stress of the complex telomeric repeats of Chironomus thummi. Chromosome Res. 16: 1085-1096.

Martinez-Guitarte, J. L., Planello, R. and Morcillo, G. 2008a. Changes in the ecdysone response pathway after exposure to different endocrine-disrupting chemicals in the aquatic larvae of Chironomus riparius. - Comp. Biochem. Physiol., Pt A,-molec. integr. Physiol. 151, Suppl.: S6-S7.

Martinez-Guitarte, J. L., Planello, R. and Morcillo, G. 2008b. Changes in the ecdysone response pathway after exposure to cadmium, pentachlorophenol and bisphenol - A in the aquatic larvae of Chironomus. - Toxic. Lett. 180, Suppl. 1: S190-S191.

Maul, J. D., Brennan, A. A., Harwood, A. D. and Lydy, M. J. 2008a. Effect of sedimentassociated pyrethroids, fipronil, and metabolites on Chironomus tentans growth rate, body mass, condition index, immobilization, and survival. - Envir. Toxic. Chem. 27: 2582-2590.

McIntosh, M. D., Schmitz, J. A., Benbow, M. E. and Burky, A. J. 2008a. Structural and functional changes of tropical riffle macroinvertebrate communities associated with stream flow withdrawal. - River Res. Applics 24: 1045-1055.

McLachlan, A. J., Pike, T. W. and Thomason, J. C. 2008a. Another kind of symmetry: Are there adaptive benefits to the arrangement of mites on an insect host? - Ethol. Ecol. Evolut. 20: $257-270$.

Mellon, C. D., Wipfli, M. S. and Li, J. L. 2008a. Effects of forest fire on headwater stream macroinvertebrate communities in eastern Washington, U.S.A. - Freshwat. Biol. 53: 2331-2343. 
Mendes, H. F. and Andersen, T. 2008a. A review of Antillocladius Sæther and Litocladius Mendes, Andersen et Sæther, with the description of two new Neotropical genera (Diptera, Chironomidae, Orthocladiinae). Zootaxa 1887: 1-75.

Mičetić, V., Bučar, M., Ivković, M., Piria, M., Krulik, I., Mihoci, I., Delić, A. and Kučinić, M. 2008a. Feeding ecology of Sabanejewia balcanica and Cobitis elongata in Croatia. Folia zool. 57: 181-190.

Michailova, P. and Jablonska-Brana, I. 2008a. Chromosome polymorphism of Camptochironomus tentans (FABRICIUS 1805) (Diptera: Chironomidae) from Łukajno (Mazurian Lakeland), Poland. - Acta zool. bulg. 50: 155-163.

Michailova, P., Krastanov, B. and Matena, J. 2008a. Chromosomal polymorphism of Chironomus plumosus (Linnaeus, 1758) (Diptera: Chironomidae) from Bulgaria (Pazardjik region) and the Czech Republic (Ceske Budejovice region). - Comp. Cytogenet. 2: 57-65.

Milesi, S. V., Biasi, C., Restello, R. M. e Hepp, L. U. 2008a. Efeito de metais Cobre (Cu) e Zinco (Zn) sobre a comunidade de macroinvertebrados bentônicos em riachos do sul do Brasil. - Acta Scient. biol. Sci. 30: 283289.

Milner, A. M., Robertson, A. L., Monaghan, K. A., Veal, A. J. and Flory, E. A. 2008a. Colonization and development of an Alaskan stream community over 28 years. - Front. Ecol. Envir. 6: 413-419.

Miserendino, M. L., Brand, C. and Di Prinzio, C. Y. 2008a. Assessing urban impacts on water quality, benthic communities and fish in streams of the Andes Mountains, Patagonia (Argentina). - Wat. Air Soil Pollut. 194: 91110.

Moller Pillot, H. K.M. 2008a. Identification and ecology of the genus Smittia Holmgren in the Netherlands (Diptera: Chironomidae). Tijdschr. Ent. 151: 245-270.

Móra, A. and Csabai, Z. 2008a. First annotated checklist of Chironomidae of Rhodos, Greece (Insecta, Diptera). - Spixiana 31: 223-231

Moubayed-Breil, J. (2007) 2008a. Non-biting midges from Continental France: new records, faunal and biogeographical outline [Diptera, Chironomidae]. - Ephemera 9: 17-32.
Moubayed-Breil, J. and Langton, P. H. (2007) 2008a. Description of Parakiefferiella normandiana sp. n. from France [Diptera, Chironomidae]. - Ephemera 9: 9-16.

Muenz, T. K., Golladay, S. W., Smith, L. L. and Vellidis, G. 2008a. Diet and abundance of Southern Two-lined Salamander larvae (Eurycea cirrigera) in streams within an agricultural landscape, southwest Georgia. SEast. Nat. 7: 691-704.

Nazarova, L. B., Pestryakova, L. A., Ushnitskaya, L. A. and Hubberten, H.-W. 2008a. (Chironomids (Diptera : Chironomidae) in lakes of central Yakutia and their indicative potential for paleoclimatic research.) - Sibirsk. ekol. Zh. 15: 141-150. [also published as: Contemp. Probl. Ecol. 1: 335-345.

Negassa, A. and Prabu, P. C. 2008a. Abundance, food habits, and breeding season of exotic Tilapia zillii and native Oreochromis niloticus L. fish species in Lake Zwai, Ethiopia. Maejo int. J. Sci. Technol. 2: 345-359.

Nelson, S. M. and Thullen, J. S. 2008a. Aquatic macroinvertebrates associated with Schoenoplectus litter in a constructed wetland in California (USA). - Ecol. Engng 33: 91101.

Néraudeau, D., Perrichot, V., Colin, J.-P., Girard, V., Gomez, B., Guillocheau, F., Masure, E., Peyrot, D., Tostain, F., Videt, B. and Vullo, R. 2008a. A new amber deposit from the Cretaceous (uppermost Albian-lowermost Cenomanian) of southwestern France. Cretac. Res. 29: 925-929.

Nessimian, J. L., Venticinque, E. M., Zuanon, J., De Marco Jr., P., Gordo, M., Fidelis, L., D’arc Batista, J. and Juen, L. 1008a. Land use, habitat integrity, and aquatic insect assemblages in Central Amazonian streams. Hydrobiologia 614: 117-131. [see: Electronic supplementary material]

Niitsuma, H. 2008a. Review of the Japanese species of Conchapelopia (Insecta: Diptera: Chironomidae), with keys to the known males and pupae. - Species Diversity 13: 73-110.

Obolewski, K. and Strzelczak, A. 2008a. MR\&CT analysis of the qualitative and quantitative structure of macrozoobenthos in selected oxbow lakes of Northern Poland. Oceanol. hydrobiol. Stud. 37: 97-104.

Ochieng, H., de Ruyter van Steveninck, E. D. and Wanda, F. M. 2008a. Mouthpart deformities in Chironomidae (Diptera) as indicators of 
heavy metal pollution in northern Lake Victoria, Uganda. - Afr. J. aquat. Sci. 33: 135142.

Olomukoro, J. O.and Okhumale, B. O. 2008a. Differential toxic response of Chironomus travalensis [sic!] kieffer [sic!] (Chironomidae: Diptera) to some industrial effluents. - Toxic. envir. Chem. 90: 1197-1202.

Olsson, K., Nyström, P., Stenroth, P., Nilsson, E., Svensson, M. and Granéli, W. 2008a. The influence of food quality and availability on trophic position, carbon signature, and growth rate of an omnivorous crayfish. - Can. J. Fish. aquat. Sci. 65: 2293-2304.

Oscoz, J., Leunda, P. M., Escala, M. C. and Miranda, R. 2008a. Summer feeding relationships of the co-occurring hatchling brown trout Salmo trutta and Ebro minnows Phoxinus bigerri in an Iberian river. - Acta zool. sin. 54: 675-685.

Ouéda, A., Guenda, W., Ouattara, A., Gourène, G., Hugueny, B. and Kabré, G. B. 2008a. Seasonal diet shift of the most important fish species in a sahelo-soudanian reservoir (Burkina Faso). - J. Fish. aquat. Sci. 3: 240251.

Oyanedel, A., Valdovinos, C., Azócar, M., Moya, C., Mancilla, G., Pedreros, P. y Figueroa, R. 2008a. Padrones de distribución espacial de los macroinvertebrados bentónicos de la cuenca del rio Aysén (Patagonia chilena). Gayana 72: 241-257.

Oyewo, E. A. and Sæther, O. A. 2008a. Revision of Polypedilum (Pentapedilum) Kieffer and Ainuyusurika Sasa et Shirasaki (Diptera: Chironomidae). - Zootaxa 1953: 1-145.

Panizzo, V. N., Jones, V. J., Birks, H. J. B., Boyle, J. F., Brooks, S. J. and Leng, M. J. 2008a. A multiproxy palaeolimnological investigation of Holocene environmental change, between c. 10700 and 7200 years BP, at Holebudalen, southern Norway. - Holocene 18: 805-817.

Park, K. and Kwak, I.-S. 2008b. Characterization of heat shock protein 40 and 90 in Chironomus riparius larvae: Effects of di(2ethylhexyl) phthalate exposure on gene expressions and mouthpart deformities. Chemosphere 74: 89-95.

Perova, S. N. 2008a. Taksonomicheskii sostav makrozoobentosa malykh karstovykh ozer Tsentral'noi Rossii. (The taxonomic composition of macrozoobenthos in central
Russian small karst lakes.) - Inland Wat. Biol. 1: 371-379.

Petrova, N. A. and Zhirov, S. V. 2008b. Polytene chromosomes of salivary glands of chironomids (Diptera: Chironomidae) from the Wrangel Island (Russia). - Comp. Cytogenet. 2: 127-130.

Posada-García, J. A., Abril-Ramírez, G. und Parra-Sánchez, L. N. 2008a. Diversidad de los macroinvertebrados acuáticos del Páramo de Frontino (Antioquia, Colombia). - Caldasia 30: 441-455.

Pozdeev, I. V. and Aleksevnina, M. S. 2008a. Rol' lichinok khironomid v structure donnykh soobshchestv rek basseina Verkhnei i Srednei Kamy. (The role of chironomid larvae in the structure of river benthic communities of the Upper and Middle Kama River basins.) Inland Wat. Biol. 1: 158-162.

Principe, R. E. 2008a. Taxonomic and size structures of aquatic macroinvertebrate assemblages in different habitats of tropical streams, Costa Rica. - Zool. Stud. 47: 525534.

Principe, R. E., Boccolini, M. F. and Corigliano, M. C. 2008a. Structure and spatial-temporal dynamics of Chironomidae fauna (Diptera) in upland and lowland fluvial habitats of the Chocancharava River basin (Argentina). - Int. Rev. Hydrobiol. 93: 342-357.

Proviz, V. I. 2008b. Vidoobrazovanie i khromosomnaya evolyutsiya endemichnykh khironomid roda Sergentia Kief. (Diptera, Chironomidae) iz ozera Baikal. Divergentsiya kariotipov i khromosomnyi polimorfizm v populyatsiyakh glubokovodnykh vidov Sergentia nebulosa Linevitsh et al. i Sergentia assimilis Proviz V. et Proviz L. (Speciation and chromosomal evolution of the Baikalian endemic chironomids of the genus Sergentia Kief. (Diptera, Chironomidae): Karyotype divergence and chromosomal polymorphism in the populations of deep-water species Sergentia nebulosa Linevitsh et al. and Sergentia assimilis Proviz V. et Proviz L.) Genetika 44: 1627-1637. [also published in: Russ. J. Genet. 44: 1409-1418.]

Pugh, P. J. A. and Convey, P. 2008a. Surviving out in the cold: Antarctic endemic invertebrates and their refugia. - J. Biogeogr. 35: 2176-2186.

Puntí, T. 2008a. Ecology of Chironomidae communities in Medeiterranean reference 
streams. - Ph. D. Thes., Univ. Barcelona. 151 pp.

Purcell, A. H., Hoffmann, A. and Resh, V. H. 2008a. Life history of a dipteran predator (Scathophagidae: Acanthocnema) of insect egg masses in a northern California stream. Freshwat. Biol. 53: 2426-2437.

Qi, X., Shi, S.-D. and Wang, X.-H. 2008a. One new record of genus Stenochironomus Kieffer in China (Diptera, Chironomidae). - Si Chuan Dong Wu (= Sichuan J. Zool.] 27: 837-838.

Qu, X.-D., Song, M.-Y., Park, Y.-S., Oh, Y. N. and Chon, T.-S. 2008a. Specis abundance patterns of benthic macroinvertebrate communities in polluted streams. - Annls Limnol. 44: 119-133.

Renouf, M. A. P. and Bell, T. 2008a. Dorset Palaeoeskimo skin processing at Phillip's Garden, Port au Choix, northwestern Newfoundland. - Arctic 61: 35-47.

Richardson, J. S. 2008a. Aquatic arthropods and forestry: effects of large-scale land use on aquatic systems in Nearctic temperate regions. - Can. Ent. 140: 495-509.

Ríos, B. 2008a. Macroinvertebrate communities in an altoandine stream: Microhabitat conditions, drift dynamics, and organic matter and oviposition relevance. - Ph. D. Thes., Univ. Barcelona. 154 pp.

Robinson, C. T., Schmid, D., Svoboda, M. and Bernasconi, S. M. 2008a. Functional measures and food webs of high elevation springs in the Swiss alps. - Aquat. Sci. 70: 432-445.

Rolland, N., Larocque, I., Francus, P., Pienitz, R. and Laperriere, L. 2008b. Evidence for a warmer period during the 12th and 13th centuries $\mathrm{AD}$ from chironomid assemblages in Southampton Island, Nunavut, Canada. Quatern. Res. 72: 27-37.

Roque, F. O. and Trivinho-Strixino, S. 2008a. Four new species of Endotribelos Grodhaus, a common fallen fruit-dwelling chironomid genus in Brazilian streams (Diptera: Chironomidae: Chironominae). - Stud. neotrop. Fauna Envir. 43: 191-207.

Ross, R. M., Long, E. S. and Dropkin, D. S. 2008a. - Response of macroinvertebrate communities to remediation-simulating conditions in Pennsylvania streams influenced by acid mine drainage. - Envir. Monit. Assess. 145: 323-338.
Sahuquillo, M., Miracle, M. R., Rieradevall, M. and Kornijów, R. 2008a. Macroinvertebrate assemblages on reed beds, with special attention to Chironomidae (Diptera), in Mediterranean shallow lakes. - Limnetica 27: 239-250.

Sakelarieva, L., Yaneva, I., Uzunov, Y., Kumanski, K., Stoichev, S., Vidinova, Y. and Tyufekchieva, V. 2008a. Taxonomic composition and dominant structure of macrozoobenthos in the Blagoevgradska Bistritsa River. - Acta zool. bulg., Suppl. 2: 201-214.

Saleh-Ahmed, R., Ismail, F. M., Abo-Ghalia, A. and El-Shenawy, N. S. 2008a. Pictorial keys of chironomid species (Order: Diptera) in ElTall El-Keber wastewater treatment plant, Egypt. - J. Ent. 5: 334-355.

Salsamendi, E., Garin, I., Almenar, D., Goiti, U., Napal, M. and Aihartza, J. 2008a. Diet and prey selection in Mehelyi's horseshoe bat Rhinolophus mehelyi (Chiroptera, Rhinolophidae) in the south-western Iberian Peninsula. - Acta chiropterol. 10: 279-286.

Sánchez-Carmona, R., Encina, L., RodríguezRuíz, A. and Rodriguez-Sánchez, V. 2008a. Age, growth and diet of the Iberian loach, Cobitis paludica in two different environments. - Folia zool. 57: 420-434.

Sanseverino, A. M. and Nessimian, J. L. 2008b. The food of larval Chironomidae (Insecta, Diptera) in submerged litter in a forest stream of the Atlantic Forest (Rio de Janeiro, Brazil). - Acta limnol. bras. 20: 15-20.

Schmidl, J., Sulzer, P. and Kitching, R. L. 2008a. The insect assemblage in water filled treeholes in a European temperate deciduous forest: community composition reflects structural, trophic and physicochemical factors. - Hydrobiologia 598: 285-303.

Schofield, K. A., Pringle, C. M., Meyer, J. L. and Rosi-Marshall, E. J. 2008a. Functional redundancy of stream macroconsumers despite differences in catchment land use. Freshwat. Biol. 53: : 2587-2599.

Sehnal, F. and Sutherland, T. 2008a. Silks produced by insect labial glands. - Prion 2: 145-153.

Sharley, D. J., Hoffmann, A. A. and Pettigrove, V. 2008a. Effects of sediment quality on macroinvertebrates in the Sunraysia region of the Murray-Darling Rivers, Australia. - Envir. Pollut. 156: 689-698. 
Shcherbina, G. Kh. 2008a. Struktura biotsenoza Dreissena polymorpha (Pallas) i rol' mollyuska v pitanii plotvy Rutilus rutilus (Linnaeus) ozera Pleshcheevo. (The structure of Dreissena polymorpha (Pallas) biocenosis and the role of mollusk in roach Rutilus rutilus (Linnaeus) feeding in Pleshcheevo Lake.) - Inland Wat. Biol. 1: 380-387.

Siebrasse, J. P., Veith, R., Dobay, A., Leonhardt, H., Daneholt, B. and Kubitscheck, U. 2008a. Discontinuous movement of mRNP particles in nucleoplasmic regions devoid of chromatin. - Proc. natn. Acad. Sci. U. S. A. 105: 2029120296.

Silva, F. L., Ruiz, S. S., Bochini, G. L. and Moreira, D. C. 2008a. Functional feeding habits of Chironomidae larvae (Insecta, Diptera) in a lotic system from Midwestern region of São Paulo State, Brazil. - Pan-Am. J. aquat. Sci. 3: 135-141.

Silva-da-Silva, L. R. 2008a. Estudo taxonômico da família Chironomidae (Diptera, Nematocera) em dois pontos lóticos e lênticos do Parque Turístico Ecológico de Penedo, Itatiaia - RJ. - Tes. Mestr., Univ. Fed. do Rio de Janeiro. 120 pp.

Sinclair, C. S. and Gresens, S. E.2008a. Discrimination of Cricotopus species (Diptera: Chironomidae) by DNA barcoding. Bull. ent. Res. 98: 555-563.

Siqueira, T., Roque, F. O. and Trivinho-Strixino, S. 2008b. Phenological patterns of neotropical lotic chironomids: Is emergence constrained by environmental factors? - Austral Ecol. 33: 902-910.

Skalskaya, I. A. , Bakanov, A. I. and Flerov, B. A. 2008a. (Study on zooperiphyton and zoobenthos of a small river.) - Inland Wat. Biol. 1: 84-92.

Sodré, V. M. 2008a. Study of the community of invertebrates in phytotelmata of Bromeliaceae with emphasis on Chironomidae (Insecta, Diptera) in a fragment of Atlantic Forest in Magé City, RJ. - Tes. Mestr., Univ. Fed. São Carlos. 65 pp.

Specziár, A. 2008a. Life history patterns of Procladius choreus, Tanypus punctipennis and Chironomus balatonicus in Lake Balaton. - Annls Limnol. 44: 181-188.

Staiber, W. 2008a. Centrosome hyperamplification with the formation of multiple asters and programmed chromosome inactivation in aberrant spermatocytes during male meiosis in Acricotopus. - Cell Tissue Res. 334: 81-91.

Stribling, J. B., Jessup, B. K. and Feldman, D. L. 2008a. Precision of benthic macroinvertebrate indicators of stream condition in Montana. - $J$. N. Am. benthol. Soc. 27: 68-67.

Stribling, J. B., Pavlik, K. L., Holdsworth, S. M. and Leppo, E. W. 2008a. Data quality, performance, and uncertainty in taxonomic identification for biological assessments. - J. N. Am. benthol. Soc. 27: 906-919.

Stur, E. and Ekrem, T. 2008a. Description of the Alpine Micropsectra oberaarensis sp. n. with taxonomic comments on the attenuata group (Diptera: Chironomidae). - Ent. fenn. 19: 142150.

Suchanek, T. H., Eagles-Smith, C. A. and Harner, E. J. 2008a. Is Clear Lake methylmercury distribution decoupled from bulk mercury loading? - Ecol. Applics 18, spec. Issue: A107-A127.

Suchanek, T. H., Eagles-Smith, C. A., Slotton, D. G., Harner, E. J., Adam, D. P., Colwell, A. E., Anderson, N, L. and Woodward, D. L. 2008a. Mine-derived mercury: effects on lower trophic species in Clear Lake, California. Ecol. Applics 18, spec. Issue: A158-A176.

Sugimaru, K., Kawai, K. and Imabayashi, H. 2008a. A new marine chironomid species of the genus Tanytarsus (Diptera: Chironomidae) from Okinawa, Japan. - Plankton Benthos Res. 3: 240-242.

Sun, X.-B. and Cui, F.-Y. 2008a. Inactivation of chironomid larvae with ozone. - Wat. Sci. Technol. Wat. Supply 8: 355-361.

Sun, X.-B. and Cui, F.-Y. 2008b. Inactivation of chironomid larvae with chlorine dioxide and chlorine. - J. Donghua Univ. Engl. Ed. 25: 361-365.

Szalinska, E., Czaplicka-Kotas, A., Vignati, D. A. L., Ferrari, B. J. D. and Dominik, J. 2008a. Bioavailability of sedimentary chromium for chironomids in the upper Dunajec River (Southern Poland). - Verh. int. Verein. Limnol. 30, 4: 534-536.

Takahashi, M. A., Higuti, J., Bagatini, Y. M., Zviejkovski, I. P. and Velho, L. F. M. 2008a. Composition and biomass of larval chironomid (Insecta, Diptera) as potential indicator of trophic conditions in southern Brazil reservoirs. - Acta limnol. bras. 20: 513. 
Tall, L., Méthot, G., Armellin, A. and PinelAlloul, B. 2008a. Bioassessment of benthic macroinvertebrates in wetland habitats of Lake Saint-Pierre (St. Lawrence River). - J. Gt Lakes Res. 34: 599-614.

Tarkowska-Kukuryk, M. and Kornijów, R. 2008a. Influence of spatial distribution of submerged macrophytes on Chironomidae assemblages in shallow lakes. - Pol. J. Ecol. 56: 569-579.

Tarkowska-Kukuryk, M. and Mieczan, T. 2008a. Diet composition of epiphytic chironomids of the Cricotopus sylvestris group (Diptera: Chironomidae) in a shallow hypertrophic lake. - Aquat. Insects 30: 285-294.

Taşdemir, A., Ustaoğlu, M. R., Balık, S. ve Sarı, H. M. 2008a. Batı Karadeniz Bölgesindeki (Türkiye) Bazı Göllerin Diptera ve Ephemeroptera Faunası. (Diptera and Ephemeroptera fauna of some lakes in Western Black Sea Region (Turkey).) - J. Fish. Sci.com 2: 252-260.

Thompson, R., Kamenik, C., Schmidt, R., Pla, S., Rieradevall, M. and Catalán, J. 2008a. Testing a new multigroup inference approach to reconstructing past environmental conditions. - J. Limnol. 67: 155-162.

Van de Meutter, F., Cottenie, K. and De Meester, L. 2008a. Exploring differences in macroinvertebrate communities from emergent, floating-leaved and submersed vegetation in shallow ponds. - Fundam. appl. Limnol. 173: 47-57.

Verberk, W. C. E. P., Siepel, H. and Esselink, H. 2008a. Life-history strategies in freshwater macroinvertebrates. - Freshwat. Biol. 53: 1722-1738.

Verberk, W. C. E. P., Siepel, H. and Esselink, H. 2008b. Applying life-history strategies for freshwater macroinvertebrates to lentic waters. - Freshwat. Biol. 53: 1739-1753.

Vidinova, Y. N., Botev, I. S., Tyufekchieva, V. G., Nedyalkova, T. V., Yaneva, I. Y., Zadneprovski, B. E. and Varadinova, E. D. 2008a. Results of rapid hydrobiological monitoring of watersheds from the East- and West Aegean Sea River Basin Districts in Bulgaria. - Acta zool. bulg. Suppl. 2: 233-242.

Vidinova, Y. N., Tyufekchieva, V. G., Yaneva, I. Y., Zadneprovski, B. E., Stoichev, S. A. and Kumanski, K. P. 2008a. Species composition and structure of macroinvertebrate communities in Arda River. - Acta zool. bulg. 60: 317-330.
Vink, J. P. M. 2008a. The origin of speciation: Trace metal kinetics over natural water/sediment interfaces and the consequences for bioaccumulation. - Envir. Pollut. 157: 519-527.

Vinogradova, E. M. 2008a. Six new species of Polypedilum Kieffer, 1912, from the Yucatán peninsula (Insecta, Diptera, Chironomidae). Spixiana 31: 277-288.

Wachalowicz, A., Czaplicka-Kotas, A. and Szalinska, E. 2008a. Bioavailability of chromium from bottom sediments for the larvae of the species Chironomus riparius. Ochrona środ. 30, 3: 53-58.

Ward, S. A. and Coburn, M. M. 2008a. Stepwise increases in maximum prey size of larval Creek Chubs, Semotilus atromaculatus, in an urbanized Ohio stream: - NEast. Nat. 15: 349362.

Waterkeyn, A., Grillas, P., Vanschoenwinkel, B. and Brendonck, L. 2008a. Invertebrate community patterns in Mediterranean temporary wetlands along hydroperiod and salinity gradients. - Freshwat. Biol. 53: 18081822.

Werner, S. and Rothhaupt, K.-O. 2008a. Effects of the invasive Asian clam Corbicula fluminea on benthic macroinvertebrate taxa in laboratory experiments. - Fundam. appl. Limnol. 173: 145-152.

Wood, P. J., Gunn, J. and Rundle, S. D. 2008a. Response of benthic cave invertebrates to organic pollution events. - Aquat. Conserv. mar. Freshwat. Ecosyst. 18: 909-922.

Wu, J.-Y. and Wang, X-H. 2008a. A first recorded species Boreochlus longicoxalsetosus (Diptera: Chironomidae: Podonominae) from China. - Si Chuan Dong Wu (= Sichuan J. Zool.] 27: 839-840.

Yamamoto, M. 2008a. Redescription of Mesosmittia patrihortae SÆTHER, 1985, from Japan (Diptera, Chironomidae). - Jap. J. syst. Ent. 14: 13-16.

Yan, C. C. and Wang, X. H. 2008a. A study on morphological intraspecific variation of Microchironomus tener (Kieffer) (Diptera: Chironomidae).- - In Wang, X. H. (ed.): Contemporary aquatic entomological study in East Asia. Proc. $3^{\text {rd }}$ Int. Symp. aquat. Ent. E. Asia, pp. 153-158. Nankai Univ. Pr., Tianjin.

Yan, C., Jin, Z. and Wang, X. 2008a. Cladopelma Kieffer from the Sino-Indian Region (Diptera: Chironomidae). - Zootaxa 1916: 44-56. 
Yan, C., Jin, Z. and Wang, X. 2008b. Paracladopelma Harnisch from the SinoIndian Region (Diptera: Chironomidae). Zootaxa 1934: 1-29.

Yan, C., Sæther, O. A., Jin, Z. and Wang, X. 2008a. Three new species of the Harnischia complex from the Sino-Indian Region, with a review of Demicryptochironomus Lenz (Diptera: Chironomidae). - Zootaxa 1968: 122.

Yıldız, S., Taşdemir, A., Balık, S. ve Ustaoğlu, M. R. 2008a. Kemer Baraj Gölü’nün (Aydın) Makrobentik (Oligochaeta, Chironomidae) Faunası. (Macrobenthic fauna (Oligochaeta, Chironomidae) of Kerner Dam Lake (Aydın).) - J. Fish. Sci.com 2: 457-465.

Zhang, R. L. and Wang, X. H. 2008b. Geographic co-evolutionarey study on Polypedilum (Cerobregma) Sæther \& Sundal (Diptera: Chironomidae.) - In Wang, X. H. (ed.): Contemporary aquatic entomological study in East Asia. Proc. $3^{\text {rd }}$ Int. Symp. aquat. Ent. E. Asia, pp. 158-171. Nankai Univ. Pr., Tianjin.

Zilli, F. L., Montalto, L., Paggi, A. C. and Marchese, M. R. 2008a. Biometry and life cycle of Chironomus calligraphus Goeldi 1905 (Diptera, Chironomidae) in laboratory conditions. - Interciencia 33: 767-770.

\section{Current Bibliography 2009}

Acosta, C. R. 2009a. (Altitudinal distribution of macroinvertebrate communities and hydrochemical characterization of karstic headwaters of the altitude river Cañete (Peru).) - Ph. D. Thes., Univ. Barcelona. 153 pp.

Agra, A. R. and Soares, A. M. V. M. 2009a. Effects of two insecticides on survival, growth and emergence of Chironomus riparius Meigen. - Bull. envir. Contam. Toxic. 82: 501504.

Ali, A., Leckel Jr., R. J., Jahan, N., Al-Shami, S. A. and Rawi, C. S. MD. 2009a. Laboratory and field investigations of pestiferous Chironomidae (Diptera) in some man-made wetlands in central Florida, USA. - J. Am. Mosquito Control Ass. 25: 94-99.

Allgood, D. W., Miller, D. A. and KalcounisRueppell, M. C. 2009a. Influence of intensive pine management on dipteran community structure in coastal North Carolina. - Envir. Ent. 38: 657-666.
Almeida, E. F., Oliveira, R. B., Mugnai, R., Nessimian, J. L. and Baptista, D. F. 2009a. Effects of small dams on the benthic community of streams in an Atlantic forest area of southeastern Brazil. - Int. Rev. Hydrobiol. 94: 179-193.

Al-Shami, S. A., Che Salmah, M. R., Siti Azizah, M. N. and Abu Hassan, A. 2009a. Distribution and abundance of Chironomidae (Diptera) in a rice rice agroecosystem in Penang, Malaysia. In: Hughes, S. J., Khadem, M. and Carvalho, M. A. (eds.): Proc. $16^{\text {th }}$ Int. Chironomid Symp., Bolm Mus. munic. Funchal (Hist. nat.), Suppl. 13: 151-160.

Álvarez, M. and Pardo, I. 2009a. Dynamics in the trophic structure of the macroinvertebrate community in a Mediterranean temporary stream. - Aquat. Sci. 71: 202-213.

Amundsen, P.-A. and Knudsen, R. 2009a. Winter ecology of Arctic charr (Salvelinus alpinus) and brown trout (Salmo trutta) in a subarctic lake, Norway. - Aquat. Ecol. 43: 765-775.

Andrei, A. E., Smith, L. M., Haukos, D. A., Surles, J. G. and Johnson, W. P. 2009a. Foraging ecology of migrant shorebirds in saline lakes of the Southern Great Plains. Waterbirds 32: 138-148.

Andrič, M., Massaferro, J., Eicher, U., Ammann, B., Leuenberger, M. C., Martinčič, A., Marinova, E. and Brancelj, A. 2009a. A multiproxy Late-glacial palaeoenvironmental record from Lake Bled, Slovenia. Hydrobiologia 631: 121-141.

Angradi, T. R., Bolgrien, D. W., Jicha, T. M., Pearson, M. S., Taylor, D. L. and Hill, B. H. 2009a. Multispatial-scale variation in benthic and snag-surface macroinvertebrate assemblages in mid-continent US great rivers. - J. N. Am. benthol. Soc. 28: 122-141.

Anjos, A. F. e Takeda, A.M. 2009a. Análise da dieta das larvas de $4^{\circ}$ estádio de Cricotopus sp. (Diptera: Chironomidae), em diferentes substratos artificiais e fases hídricas, no trecho superior do rio Paranà. - Acta Scient.biol. Sci. 31: 371-377.

Anonymus 2009a. Anna Andreevna Linevitsh. Evraziat. ent. Zh. (= Euroas. ent. J.) 8, Suppl. 1: 3-5.

Arimoro, F. O. and Ikomi, R. B. 2009a. Ecological integrity of upper Warri River, Niger Delta using aquatic insects as bioindicators. - Ecol. Indicators 9: 455-461. 
Axford, Y., Briner, J. P., Miller, G. H. and Francis, D. R. 2009a. Paleoecological evidence for abrupt cold reversals during peak Holocene warmth on Baffin Island, Arctic Canada. - Quatern. Res. 71: 142-149.

Axford, Y., Geirsdóttir, Á., Miller, G. H. and Langdon, P. G. 2009a. Climate of the Little Ice Age and the past 2000 years in northeast Iceland inferred from chironomids and other lake sediment proxies. - J. Paleolimnol. 41: 724.

Babrekar, A. A. 2009a. The role of iron in the homeostasis \& abiotic stress response in Chironomus ramosus. - Ph. D. Thes., Univ. Pune. 117 pp.

Baldigo, B. P., Lawrence, G. B., Bode, R. W., Simonin, H. A., Roy, K. M. and Smith, A. J. 2009a. Impacts of acidification on macroinvertebrate communities in streams of the western Adirondack Mountains, New York, USA. - Ecol. Indicators 9: 226-239.

Barquín, J. and Death, R. G.2009a. Physical and chemical differences in karst springs of Cantabria, northern Spain: do invertebrate communities correspond? - Aquat. Ecol. 43: 445-455.

Barriga, J. P. and Battini, M. A. 2009a. Ecological significances of ontogenetic shifts in the stream-dwelling catfish, Hatcheria macraei (Siluriformes, Trichomycteridae), in a Patagonian river. - Ecol. Freshwat. Fish 18: 395-405.

Benoit, J. B., Lopez-Martinez, G., Elnitsky, M. A., Lee Jr., R. E. and Denlinger, D. L. 2009a. Dehydration-induced cross tolerance of Belgica antarctica larvae to cold and heat is facilitated by trehalose accumulation. - Comp. Biochem. Physiol. - A molec. integrat. Physiol. 152: 518-523.

Benstead, J. P., March, J. G., Pringle, C. M., Ewel, K. C. and Short, J. W. 2009a. Biodiversity and ecosystem function in species-poor communities: community structure and leaf litter breakdown in a Pacific island stream. - J. N. Am. benthol. Soc. 28: 454-465.

Bertrand, K. N., Gido, K. B., Dodds, W. K., Murdock, J. N. and Whiles, M. R. 2009a. Disturbance frequency and functional identity mediate ecosystem processes in prairie streams. - Oikos 118: 917-933.

Bickel, T. O. and Closs, G. P. 2009a. Impact of partial removal of the invasive macrophyte
Lagarosiphon major (Hydrocharitaceae) on invertebrates and fish. - River Res. Applics 25: 734-744.

Bilton, D. T., McAbendroth, L. C., Nicolet, P., Bedford, A., Rundle, S. D., Foggo, A. and Ramsay, P. M. 2009a. Ecology and conservation status of temporary and fluctuating ponds in two areas of southern England. - Aquat. Conserv. mar. Freshwat. Ecosyst. 19: 134-146.

Biswas, J. K., Rana, S., Bhakta, J. N. and Jana, B. B. 2009a. Bioturbation potential of chironomid larvae for the sediment-water phosphorus exchange in simulated pond systems of varied nutrient enrichment. - Ecol. Engng 35: 1444-1453.

Bitušík, P., Kubovčík, V., Štefková, E., Appleby, P. G. and Svitok, M. 2009a. Subfossil diatoms and chironomids along an altitudinal gradient in the High Tatra Mountain lakes: a multiproxy record of past environmental trends. Hydrobiologia 631: 65-85.

Björk, P., Jin, S., Zhao, J., Singh, O. P., Persson, J.-O., Hellman, U. and Wieslander, L. 2009a. Specific combinations of SR proteins associate with single pre-messenger RNAs in vivo and contribute different functions. - $J$. Cell Biol. 184: 555-568.

Blocksom, K. A. and Johnson, B. R. 2009a. Development of a regional macroinvertebrate index for large river bioassessment. - Ecol. Indicators 9: 313-328.

Boakye, D. A., Fokam, E., Ghansah, A., Amakye, J., Wilson, M. D. and Brown, C. A. 2009a. Cardiocladius oliffi (Diptera: Chironomidae) as a potential biological control agent against Simulium squamosum (Diptera: Simuliidae). Parasites Vectors 2, 20: 5 pp.

Bogut, I., Vidakovic, J., Cerba, D. and Palijan, G. 2009a. Epiphytic meiofauna in stands of different submerged macrophytes. - Ekoloji 18, 70: 1-9.

Boonsoong, B., Sangpradub, N. and Barbour, M. T. 2009a. Development of rapid bioassessment approaches using benthic macroinvertebrates for Thai streams. - Envir. Monit. Assess. 155: 129-147.

Borza, P., Erős, T. and Oertel, N. 2009a. Food resource partitioning between two invasive gobiid species (Pisces, Gobiidae) in the littoral zone of the River Danube, Hungary. - Int. Rev. Hydrobiol. 94: 609-621. 
Bouchard Jr., R. W. and Ferrington Jr., L. C. 2009a. Winter growth, development, and emergence of Diamesa mendotae (Diptera: Chironomidae) in Minnesota streams. - Envir: Ent. 38: 250-259.

Bouchard Jr., R. W. and Ferrington Jr., L. C. 2009b. Determination of Chironomidae thermal preferences and thermal partitioning among closely related taxa in a Minnesota stream using surface floating pupal exuviae. In: Hughes, S. J., Khadem, M. and Carvalho, M. A. (eds.): Proc. $16^{\text {th }}$ Int. Chironomid Symp., Bolm Mus. munic. Funchal (Hist. nat.), Suppl. 13: 191-198.

Bredenhand, E. and Samways, M. J. 2009a. Impact of a dam on benthic macroinvertebrates in a small river in a biodiversity hotspot: Cape Floristic Region, South Africa. - J. Insect Conserv. 13: 297307.

Brodin, Y. and Andersson, M. H.2009a. The marine splash midge Telmatogon [sic!] japonicus (Diptera; Chironomidae) - extreme and alien? - Biol. Invasions 11: 1311-1317.

Buczkó, K., Magyari, E. K., Bitušík, P. and Wacnik, A. 2009a. Review of dated Late Quaternary palaeolimnological records in the Carpathian Region, east-central Europe. Hydrobiologia 631: 3-28.

Bunbury, J. and Gajewski, K. 2009a. Postglacial climates inferred from a lake at treeline, southwest Yukon Territory, Canada. Quatern. Sci. Rev. 28: 354-369.

Burdett, A. S. and Watts, R. J. 2009a. Modifying living space: an experimental study of the influences of vegetation on aquatic invertebrate community structure Hydrobiologia 618: 161-173.

Burton, T. M. and Uzarski, D. G. 2009a. Biodiversity in protected coastal wetlands along the weast coast of Lake Huron. - Aquat. Ecosyst. Hlth Mgmt 12: 63-76.

Caldwell, B. A. 2009a. Chironomus oceanicus Packard, 1869, a new junior synonym of Halocladius variabilis (Staeger, 1839) (Diptera: Chironomidae). - In: Hughes, S. J., Khadem, M. and Carvalho, M. A. (eds.): Proc. $16^{\text {th }}$ Int. Chironomid Symp., Bolm Mus. munic. Funchal (Hist. nat.), Suppl. 13: 207212.

Campbell, B. D., Haro, R. J. and Richardson, W. B. 2009a. Effects of agricultural land use on chironomid communities: comparisons among natural wetlands and farm ponds. - Wetlands 29: $1070-1080$.

Cañedo-Argüelles, M. 2009a. Ecology of macroinvertebarete communities in transitional waters: Influence of the environment, response to disturbance and successional processes. - Ph. D. Thes., Univ. Barcelona. 226 pp.

Cañedo-Argüelles, M. and Rieradevall, M. 209a. Qusantification of environment-driven changes in epiphytic macroinvertebrate communities associated with Phragmites australis. - J. Limnol. 68: 229-241.

Casatti, L., Júnior, J. L. V. e Ferreira, C. P. 2009a. Dieta do cascudo Aspidoras fuscoguttatus (Ostariophysi, Callichthyidae) em riachos com diferentes características limnológicas e estruturais. - Biota neotrop. 9, 1, bn02309012009: 113-122.

Chan, E. K. W., Zhang, Y. and Dudgeon, D. 2009a. Substrate availability may be more important than aquatic insect abundance in the distribution of riparian orb-web spiders in the tropics. - Biotropica 41: 196-201.

Charman, D. J., Barber, K. E., Blaauw, M., Langdon, P. G., Mauquoy, D., Daley, T. J., Hughes, P. D. M. and Karofeld, E. 2009a. Climate drivers for peatland palaeoclimate records. - Quatern. Sci. Rev. 28: 1811-1819.

Cheng, M. and Wang, X. 2009a. Thienemannimyia Fittkau (Diptera: Chironomidae) from China. - Zootaxa 2074: 50-60.

Chibunda, R. T. 2009a. Chronic toxicity of mercury ( $\mathrm{HgCl} 2)$ to the benthic midge Chironomus riparius. - Int. J. envir. Res. 3: 455-462.

Choi, J. and Ha, M.-H. 2009a. Effect of cadmium exposure on the globin protein expression in 4th instar larvae of Chironomus riparius Mg. (Diptera: Chironomidae): An ecotoxicoproteomics approach. - Proteomics 9: 31-39.

Chowdhury, N., Chatterjee, S. K., Laskar, S. and Chandra, G. 2009a. Larvicidal activity of Solanum villosum Mill (Solanaceae: Solanales) leaves to Anopheles subpictus Grassi (Diptera: Culicidae) with effect on non-target Chironomus circumdatus Kieffer (Diptera: Chironomidae). - J. Pest Sci. 82: 1318.

Como, S. and Magni, P. 2009a. Temporal changes of a macrobenthic assemblage in 
harsh lagoon sediments. - Estuar. coast. Shelf Sci. 83: 638-646.

Corbi, J. J. and Trivinho-Strixino, S. 2009a. Effects of land use on lotic chironomid communities of southeast of Brazil: emphasis on the impact of sugar cane cultivation. - In: Hughes, S. J., Khadem, M. and Carvalho, M. A. (eds.): Proc. $16^{\text {th }}$ Int. Chironomid Symp., Bolm Mus. munic. Funchal (Hist. nat.), Suppl. 13: $93-100$

Corcoran, R. M., Lovvorn, J. R. and Heglund, P. J. 2009a. Long-term change in limnology and invertebrates in Alaskan boreal wetlands. Hydrobiologia 620: 77-89.

Cranston, P. S. 2009a. A new genus of transTasman midge: Anzacladius gen. n. (Diptera: Chironomidae: Orthocladiinae). - Aust. J. Ent. 48: 130-139.

Cuppen, H., Klink, A. and Moller Pillot, H. 2009a. The larvae of Graceus ambiguus and Sergentia near prima and their identification. Lauterbornia 67: 29-37.

Datkhile, K. D., Dongre, T. K., Mukhopadhyaya, R. and Nath, B. B. 2009a. Gamma radiation tolerance of a tropical species of midge, Chironomus ramosus Chaudhuri (Diptera: Chironomidae). - Int. J. Radiat. Biol. 85: 495503.

Datkhile, K. D., Mukhopadhyaya, R., Dongre, T. K. and Nath, B. B. 2009a. Increased level of superoxide dismutase (SOD) activity in larvae of Chironomus ramosus (Diptera: Chironomidae) subjected to ionizing radiation. - Comp. Biochem. Physiol. Pt C Toxic. Pharmacol. 149: 500-506.

De Jonge, M., Dreesen, F., De Paepe, J., Blust, R. and Bervoets, L. 2009a. Do acid volatile sulfides (AVS) influence the accumulation of sediment-bound metals to benthic invertebrates under natural field conditions? Envir. Sci. Technol. 43: 4510-4516.

De Lange, H. J., Peeters, E. T. H. M., Harmsen, J., Maas, H. and De Jonge, J. 2009a. Seasonal variation of total and biochemically available concentrations of PAHs in a floodplain lake sediment has no effect on the benthic invertebrate community. - Chemosphere 75: 319-326.

Ding, Y., You, J. and Lydy, M. J. 2009a. Analysis of pyrethroid insecticides in Chironomus dilutus using matrix solid phase dispersion extraction. - Bull. envir. Contam. Toxic. 83: 388-392.
Di Veroli, A., Goretti, E., Marcucci, C., Fabrizi, A., Scopetta, L. and Di Giovanni, M. V. 2009a. Incidence of larvae mouthpart deformities in Chironomus plumosus (DIPTERA: CHIRONOMIDAE) and Procladius sp. (DIPTERA: CHIRONOMIDAE) from Piediluco Lake, Italy. - In: Hughes, S. J., Khadem, M. and Carvalho, M. A. (eds.): Proc. $16^{\text {th }}$ Int. Chironomid Symp., Bolm Mus. munic. Funchal (Hist. nat.), Suppl. 13: 13-20.

Dörner, H., Skov, C., Berg, S., Schulze, T., Beare, D. J. and van der Velde, G. 2009a. Piscivory and trophic position of Anguilla anguilla in two lakes: importance of macrozoobenthos density. - J. Fish Biol. 74: 2115-2131.

Dombrovskii, K. O. 2009a. Znachenie dvustvorchatykh mollyuskov $\mathrm{v}$ obrazovanii konsortsii vodnykh bespozvonochnykh $\mathrm{V}$ litorali iskusstvennogo evtrofnogo ozera. (Role of bivalve mollusks in formation of aquatic invertebrate consortia in the littoral zone of an artificial lake,) - Ekologiya 2009, 2: 127-132. [also published in: Russ. J. Ecol. 40: 116-120.]

Domingues, I., Guilhermino, L., Soares, A. M. V. M., Nogueira, A. J. A. and Monaghan, K. A. 2009a. Influence of exposure scenario on pesticide toxicity in the midge Kiefferulus calligaster (Kieffer). - Ecotoxic. envir. Saf. 72: 450-457.

Dornfeld, C. B., Moreira-Santos, M., Espíndola, E. L. G. and Ribeiro, R. 2009a. Do larvae and ovipositing Chironomus riparius (Diptera: Chironomidae) females avoid coppercontaminated environments? - Hum. ecol. Risk Assess. 15. 63-75.

Dubois, M. and Hare, L. 2009a. Selenium assimilation and loss by an insect predator and its relationship to Se subcellular partitioning in two prey types. - Envir. Pollut. 157: 772777.

Dubois, M. and Hare, L. 2009b. Subcellular distribution of cadmium in two aquatic invertebrates: change over time and relationship to $\mathrm{Cd}$ assimilation and loss by a predatory insect. - Envir. Sci. Technol. 43: 356-361.

Dukowska, M., Grzybkowska, M., Marszał, L. and Zięba, G. 2009a. The food preferences of three-spined stickleback, Gasterosteus aculeatus L., downstream from a dam 
reservoir. - Oceanol. hzydrobiol. Stud. 38: 3950.

Durance, I. and Ormerod, S. J. 2009a. Trends in water quality and discharge confound longterm warming effects on river macroinvertebrates. - Freshwat. Biol. 54: 388405.

Durnova, N. A. 2009a. Khromosomnyi polimorfizm i tsitotipy Endochironomus tendens F. (Diptera, Chironomidae) iz vodoemov Saratovskoi i Samarskoi oblastei. (Chromosome polymorphism and cytotypes of Endochironomus tendens F. (Diptera, Chironomidae) from Saratov and Samara regions.) - Tsitologiya 51: 592-601. [also published in: Cell Tissue Biol. 3: 340-348.]

Dussault, E. B., Balakrishnan, V. K., Borgmann, U., Solomon, K. R. and Sibley, P. K. 2009a. Bioaccumulation of the synthetic hormone $17 \alpha$-ethinylestradiol in the benthic invertebrates Chironomus tentans and Hyalella azteca. - Ecotoxic. envir. Saf. 72: 1635-1641.

Dussault, E. B., Balakrishnan, V. K., Solomon, K. R. and Sibley, P. K. 2009a. Matrix effects on mass spectrometric determinations of four pharmaceuticals and personal care products in water, sediments, and biota. - Can. J. Chem. 87: 662-672.

Ekrem, T. and Stur, E. 2009a. A review of the genus Zavrelia (Diptera: Chironomidae). Eur. J. Ent. 106: 119-144.

Eldridge, J. L., Krapu, G. L. and Johnson, D. H. 2009a. Feeding ecology of Arctic-nesting sandpipers during spring migration Ttrough the Prairie Pothole Region. - J. Wildl. Mgmt 73: 248-252.

Engels, S., Bohncke, S. J. P., Bos, J. A. A., Helmens, K. and Heiri, O. 2009a. Chironomid-based inferences of local and regional environmental change during the early Middle Weichselian in Northeast Finland. - In: Hughes, S. J., Khadem, M. and Carvalho, M. A. (eds.): Proc. $16^{\text {th }}$ Int. Chironomid Symp., Bolm Mus. munic. Funchal (Hist. nat.), Suppl. 13: 185-190.

Ermolaeva, O. V. 2009a. Kariotip Diamesa hamaticornis Kieffer, 1924 (Diptera, Chironomidae) i sravnitel'nyi kariologicheskii analiz vidov v rode Diamesa Meigen. (The karyotype of Diamesa hamaticornis Kieffer, 1924 (Diptera, Chironomidae) and a comparative karyological analysis of Diamesa
Meigen species. - Evraziat. ent. Zh. (= Euroas. ent. J.) 8, Suppl. 1: 29-32.

Fernández, H. R., Romero, F. and Domínguez, E. 2009a. Intermountain basins use in subtropical regions and their influences on benthic fauna. - River Res. Applics 25: 181-193.

Ferns, P. N. and Reed, J. P. 2009a. Effects of the Cardiff Bay tidal barrage on the abundance, ecology and behaviour of shelducks Tadorna tadorna. - Aquat. Conserv. mar. Freshwat. Ecosyst. 19: 466-473.

Ferrington Jr., L. C., Masteller, E. C. and Santiago-Blay, J. A. 2009a. Comparison and significance of Chironomidae emergence from Lake Erie and Presque Isle Bay, Erie, Pennsylvania, U. S. A. - In: Hughes, S. J., Khadem, M. and Carvalho, M. A. (eds.): Proc. $16^{\text {th }}$ Int. Chironomid Symp., Bolm Mus. munic. Funchal (Hist. nat.), Suppl. 13: 21-28.

Filippov, A. A. and Riedel, F. 2009a. The late Holocene mollusc fauna of the Aral Sea and its biogeographical and ecological interpretation. - Limnologica 39: 67-85.

Free, G., Bowman, J., McGarrigle, M., Caroni, R., Donnelly, K., Tierney, D., Trodd, W. and Little, R. 2009a. The identification, characterization and conservation value of isoetid lakes in Ireland. - Aquat. Conserv. mar. Freshwat. Ecosyst. 19: 264-273.

Free, G., Solimini, A. G., Rossaro, B., Marziali, L., Giacchini, R., Paracchini, B., Ghiani, M., Vaccaro, S., Gawlik, B. M., Fresner, R., Santner, G., Schönhuber, M. and Cardoso, A. C. 2009a. Modelling lake macroinvertebrate species in the shallow sublittoral: relative roles of habitat, lake morphology, aquatic chemistry and sediment composition. Hydrobiologia 633: 123-136.

French III, J. R. P., Schaeffer, J. S., Roseman, E. F., Kiley, C. S. and Fouilleroux, A. 2009a. Abundance and distribution of benthic macroinvertebrates in offshore soft sediments in Western Lake Huron, 2001-2007. - J. Gt Lakes Res. 35: 120-127.

Friberg, N., Dybkjær, J. B., Olafsson, J. S., Gislason, G. M., Larsen, S. E. and Lauridsen, T. L. 2009a. Relationships between structure and function in streams contrasting in temperature. - Freshwat. Biol. 54: 2051-2068.

Frouz, J., Lobinske, R. J. and Ali, A. 2009a. Intraspecific competition of Glyptotendipes paripes (Diptera: Chironomidae) under 
laboratory conditions. - Aquat. Ecol. 43: 487500 .

Fu, Y. and Wang, X. 2009a. Four new species of Nanocladius Kieffer from Oriental China (Diptera: Chironomidae: Orthocladiinae). Zootaxa 1985: 43-51.

Fusari, L. M., Roque, F. O. and Hamada, N. 2009a. Oukuriella pesae, new species of sponge-dwelling chironomid (Insecta: Diptera) from Amazonia, Brazil. - Zootaxa 2146: 61-68.

Gallardo, B., Gascón, S., García, M. and Comín, F. A. 2009a. Testing the response of macroinvertebrate functional structure and biodiversity to flooding and confinement. - $J$. Limnol. 68: 315-326.

Garbary, D. J., Jamieson, M. M. and Taylor, B. R. 2009a. Population ecology of the marine insect Halocladius variabilis (Diptera: Chironomidae) in the rocky intertidal zone of Nova Scotia, Canada. - Mar. Ecol. Prog. Ser. 376: 193-202.

Gathorne-Hardy, F. J., Erlendsson, E., Langdon, P. G. and Edwards, K. J. 2009a. Lake sediment evidence for late Holocene climate change and landscape erosion in western Iceland. - J. Paleolimnol. 42: 413-426.

Giddings, J. M., Barber, I. and Warren-Hicks, W. 2009a. Comparative aquatic toxicity of the pyrethroid insecticide lambda-cyhalothrin and its resolved isomere gamma.cyhalothrin. Ecotoxicology 18: 239-249.

Giłka, W. 2009a. Order Diptera, family Chironomidae - tribe Tanytarsini. - In: Harten, A. van (ed.): Arthropod fauna of the United Arab Emirates, vol. 2: 667-682. Dar Al Ummah Print., Publ., Distrib., Advertis., Abu Dhabi.

Giłka, W. and Paasivirta, L. 2009a. Evaluation of diagnostic characters of the Tanytarsus chinyensis group (Diptera: Chironomidae), with description of a new species from Lapland. - Zootaxa 2197: 31-42.

Gillies, C. L., Hose, G. C. and Turak, E. 2009a. What do qualitative rapid assessment collections of macroinvertebrates represent? A comparison with extensive quantitative sampling. - Envir. Monit. Assess. 149: 99-112.

Gonçalves, A. L. and Canhoto, C. 2009a. Decomposition of eucalypt and alder mixtures: responses to variation in evenness. Fundam. appl. Limnol. 173: 293-303.
Grabowska, J., Grabowski, M. and Kostecka, A. 2009a. Diet and feeding habits of monkey goby (Neogobius fluviatilis) in a newly invaded area. - Biol. Invasions 11: 2161-2170.

Grabowska, J., Grabowski, M., Pietraszewski, D. and Gmur, J. 2009a. Non-selective predator the versatile diet of Amur sleeper (Percottus glenii Dybowski, 1877) in the Vistula River (Poland), a newly invaded ecosystem. - J. appl. Ichthyol. 25: 451-459.

Green, P. 2009a. The response of chironomids to water and sediment chemistry in urban canals. - In: Hughes, S. J., Khadem, M. and Carvalho, M. A. (eds.): Proc. $16^{\text {th }}$ Int. Chironomid Symp., Bolm Mus. munic. Funchal (Hist. nat.), Suppl. 13: 29-37.

Gremyatchikh, V. A., Tomilina, I. I. i Grebenyuk, L. P. 2009a. Vliyanie khlorida rtuti na morfofunktsional'nye pokazateli lichinok Chironomus riparius Meigen (Diptera, Chironomidae). (The effect of mercury chloride on morphofunctional parameters in Chironomus riparius Meigen (Diptera, Chironomidae) larvae.) - Biol. vnutr. Vod 2009, 1: 94-101. [also published in: Inland Wat. Biol. 2,1: 89-95.]

Gresens, S. E. and Ferrington Jr., L. C. 2009a. Taxonomic distinctness provides an alternative view of the diversity of Chironomidae (Diptera) assemblages. - In: Hughes, S. J., Khadem, M. and Carvalho, M. A. (eds.): Proc. $16^{\text {th }}$ Int. Chironomid Symp., Bolm Mus. munic. Funchal (Hist. nat.), Suppl. 13: 101-108.

Grohs, K. L., Klumb, R. A., Chipps, S. R. and Wanner, G. A. 2009a. Ontogenetic patterns in prey use by pallid sturgeon in the Missouri River, South Dakota and Nebraska. - J. appl. Ichthyol. 25, s2: 48-53.

Guilizzoni, P., Massaferro, J., Lami, A., Piovano, E. L., Guevara, S. R., Formica, S. M., Daga, R., Rizzo, A. and Gerli, S. 2009a. Palaeolimnology of Lake Hess (Patagonia, Argentina): multi-proxy analyses of short sediment cores. - Hydrobiologia 631: 289312.

Gunderina, L. I., Kiknadze, I. I., Istomina, A. G. and Butler, M. 2009a. Geograficheskaya differentsiatsiya genomnoi DNK Chironomus plumosus (Diptera, Chironomidae) v prirodnykh populyatsiyakh Golarktiki. (Geographic differentiation of genomic DNA of Chironomus plumosus (Diptera, Chironomidae) in natural holarctic 
populations.) - Genetika 45: 64-72. [also published in: Russ. J. Genet. 45: 54-62.]

Gunkel, G., Beulker, C., Hoffmann, A. and Kosmol, J. 2009a. Fine particulate organic matter (FPOM) transport and processing in littoral interstices - use of fluorescent markers. - Limnologica 39: 185-199.

Halpern, M., Shakéd, T., Pukall, R. and Schumann, P. 2009a. Leucobacter chironomi sp. nov., a chromate-resistant bacterium isolated from a chironomid egg mass. - Int. J. syst. evolut. Microbiol. 50: 665-670.

Hanson, M. A., Bowe, S. E., Ossman, F. G., Fieberg, J., Butler, M. G. and Koch, R. 2009a. Influences of forest harvest and environmental gradients on aquatic invertebrate communities of seasonal ponds. - Wetlands 29: 884-895.

Hargrave, C. W. 2009a. Effects of fish species richness and assemblage composition on stream ecosystem function. - Ecol. Freshwat. Fish 18: 24-32.

Hargrave, C. W., Gary, K. P. and Rosado, S. K. 2009a. Potential effects of elevated atmospheric carbon dioxide on benthic autotrophs and consumers in stream ecosystems: a test using experimental stream mesocosms. - Global Change Biol. 15: 27792790.

Harwood, A. D., You, J. and Lydy, M. J. 2009a. Temperature as a toxicity identification evaluation tool for pyrethroids insecticides: toxicokinetic vconfirmation. - Envir. Toxic. Chem. 28: 1051-1058.

Heino, J., Ilmonen, J., Kotanen, J., Mykrä, H., Paasivirta, L., Soininen, J. and Virtanen, R. 2009a. Surveying biodiversity in protected and managed streams: Algae, macrophytes and macroinvertebrates in boreal forest streams. - Ecol. Indicators 9: 1179-1187.

Heiri, O. and Lotter, A. F. 2009a. Chironomidae (Diptera) in Alpine lakes: a study of subfossil assemblages in lake surface sediments. - In: Hughes, S. J., Khadem, M. and Carvalho, M. A. (eds.): Proc. $16^{\text {th }}$ Int. Chironomid Symp., Bolm Mus. munic. Funchal (Hist. nat.), Suppl. 13: 177-184.

Helmens, K. F., Risberg, J., Jansson, K. N., Weckström, J., Berntsson, A., Tillman, P. K., Johansson, P. W. and Wastegård, S. 2009a. Early MIS 3 glacial lake evolution, icemarginal retreat pattern and climate at Sokli (northeastern Fennoscandia). - Quatern. Sci. Rev. 28: 1880-1894.
Hessle, V., Björk, P., Sokolowski, M., Valdivia, E. G. de, Silverstein, R., Artemenko, K., Tyagi, A., Maddalo, G., Ilag, L., Helbig, R., Zubarev, R. A. and Visa, N. 2009a. The exosome associates cotranscriptionally with the nascent pre-mRNP through interactions with heterogeneous nuclear ribonucleoproteins. - Molec. Biol. Cell 20: 3459-3470.

Henriques-Oliveira, A. L., Silva, R. A. and Nessimian, J. L. 2009a. First recorded [sic!] of Pontomyia Edwards, 1926 (Diptera: Chironomidae: Tanytarsini) in Brazil. -Biota neotrop. 9,1, bn02309012009: 271-274.

Hirabayashi, K., Yoshizawa, K., Oga, K., Yoshida, N., Ariizumi, K. and Kazama, F. 2009a. Change of chironomid fauna (Diptera: Chironomidae) in eutrophic Lake Kawaguchi, Japan. - In: Hughes, S. J., Khadem, M. and Carvalho, M. A. (eds.): Proc. $16^{\text {th }}$ Int. Chironomid Symp., Bolm Mus. munic. Funchal (Hist. nat.), Suppl. 13: 109-117.

Hoang, T. C., Schuler, L. J., Rogevich, E. C., Bachman, P. M., Rand, G. M. and Frakes, R. A. 2009a. Copper release, speciation, and toxicity following multiple floodings of copper enriched agriculture soils: implications in Everglades restoration. - Wat. Air Soil Pollut. 199: 79-93.

Höckelmann, C., Becher, P. G., Von Reuß, S. H. and Jüttner, F. 2009a. Sesquiterpenes of the geosmin-producing cyanobacterium Calothrix PCC 7507 and their toxicity to invertebrates. Z. Naturforsch. Sect. C, J. Biosci. 64: 49-55.

Hoekman, D., Winston, R. and Mitchell, N. 2009a. Top-down and bottom-up effects of a processing detritivore. - J. N. Am. benthol. Soc. 28:552-559.

Holmes, N., Langdon, P. G. and Caseldine, C. J. 2009a. Subfossil chironomid variability in surface sediment samples from Icelandic lakes: implications for the development and use of training sets. - J. Paleolimnol. 42: 281295.

Horikawa, D. D., Iwata, K. I., Kawai, K., Koseki, S., Okuda, T. and Yamamoto, K. 2009a. High hydrostatic pressure tolerance of four different anhydrobiotic animal species. - Zool. Sci. 26: 238-242.

Hormes, A., Blaauw, M., Dahl, S. O., Nesje, A. and Possnert, G. 2009a. Radiocarbon wigglematch dating of proglacial lake sediments Implications for the 8.2 ka event. - Quatern. Geochronol. 4: 267-277. 
Hu, Z.-J., Liu, Q.-G., Chen, L.-J. and Peng, Z.-R. 2009a. (Structural characteristics of chironomid community and their indicative significance in bioassessment of water quality in Mingzhu Lake of Chongming Island, Shanghai.) - Chin. J. appl. Ecol. 20: 929-936.

Huddleston III, G. M., Dorn, P. B., Gillespie Jr., W. B., Wong, D. C. and Slocomb, J. P. 2009a. Assessment of the ecological effects of arsenic on a southern Ohio, USA stream. Integr. envir. Assess. Mgmt 5: 302-319.

Hughes, S. J., Khadem, M. and Carvalho, M. A. 2009a. Foreword. - In: Hughes, S. J., Khadem, M. and Carvalho, M. A. (eds.): Proc. $16^{\text {th }}$ Int. Chironomid Symp., Bolm Mus. munic. Funchal (Hist. nat.), Suppl. 13: 1.

Hunter, W., Yang, Y., Reichenberg, F., Mayer, P. and Gan, J. 2009a. Measuring pyrethroids in sediment porewater using matrix-solid phase microextraction. - Envir. Toxic. Chem. 28: 3643.

Hutchens Jr., J. J., Schuldt, J. A., Richards, C., Johnson, L. B., Host, G. E. and Breneman, D. H. 2009a. Multi-scale mechanistic indicators of Midwestern USA stream macroinvertebrates. - Ecol. Indicators 9: 1138-1150.

Ilmonen, J., Paasivirta, L., Virtanen, R. and Muotka, T. 2009a. Regional and local drivers of macroinvertebrate assemblages in boreal springs. - J. Biogeogr. 36: 822-834.

Ilyashuk, B., Gobet, E., Heiri, O., Lotter, A. F., van Leeuwen, J. F. N., van der Knaap, W. O., Ilyashuk, E., Oberli, F. and Ammann, B. 2009a. Lateglacial environmental and climatic changes at the Maloja Pass, Central Swiss Alps, as recorded by chironomids and pollen. - Quatern. Sci. Rev. 28: 1340-1353.

Inoue, E., Kimura, G., Denda, M., Tokioka, T., Tsushima, K., Amano, K. and Hirabayashi, K. 2009a. Usefulness and problems of larval rearing for assessment of lotic chironomid assemblages: a case study in a riffle/pool section at the middle reaches of the Shinano River, Japan. - In: Hughes, S. J., Khadem, M. and Carvalho, M. A. (eds.): Proc. 16 ${ }^{\text {th }}$ Int. Chironomid Symp., Bolm Mus. munic. Funchal (Hist. nat.), Suppl. 13: 119-126.

Ioannou, C. C. and Krause, J. 2009a. Interactions between background matching and motion during visual detection can explain why cryptic animals keep still. - Biol. Lett. 5: 191193.
Istomina, A. G., Kiknadze, I. I. i Gunderina, L. I. 2009a. Khromosomnaya izmenchivost' v prirodnykh populyatsiyakh Chironomus cingulatus Meigen (Diptera, Chironomidae). (Chromosomal variability in natural populations of Chironomus cingulatus Meigen (Diptera, Chironomidae).) - Tsitologiya 51: 138-148. [also published in: Cell Tissue Biol. 3: 149-161.]

Jabłońska-Barna, I. and Michailova, P. 2009a. Cytogenetic characteristics of species of the Chironomus genus (Diptera, Chironomidae) from Lake Łuknajno Biosphere Reserve (northwest Poland). - Oceanol. hydrobiol. Stud. 38: 77-81.

Jacobsen, R. E. 2009a. Midge (DIPTERA: CHIRONOMIDAE and CERATOPOGONIDAE) community response to canal discharge into Everglades National Park, Florida. - In: Hughes, S. J., Khadem, M. and Carvalho, M. A. (eds.): Proc. $16^{\text {th }}$ Int. Chironomid Symp., Bolm Mus. munic. Funchal (Hist. nat.), Suppl. 13: 39-50.

James, A. B. W., Dewson, Z. S. and Death, R. G. 2009a. The influence of flow reduction on macroinvertebrate drift density and distance in three New Zealand streams. - J. N. Am. benthol. Soc. 28: 220-232.

James, R. 2009a. Temporal costs of feeding and predation rates in Betta splendens (Regan) in relation to body weight, feed type and sex. Trop. Life Sci. Res. 20: 7-16.

Jungmann, D., Bandow, C., Gildemeister, T., Nagel, R., Preuss, T. G., Ratte, H. T., Shinn, C., Weltje, L. and Maes, H. M. 2009a. Chronic toxicity of fenoxycarb to the midge Chironomus riparius after exposure in sediments of different composition. - J. Soils Sediments 9: 94-102.

Kaiser, T. S. and Heckel, D. G. 2009a. Isolation of 10 polymorphic microsatellite loci in the marine midge Clunio marinus (Chironomidae, Diptera) and their efficient characterization by heteroduplex analysis. - Molec. Ecol. Resourc. 9: 195-198.

Karouna-Renier, N. K. and Rao, K. R. 2009a. An inducible HSP70 gene from the midge Chironomus dilutus: characterization and transcription profile under environmental stress. - Insect molec. Biol. 18: 87-96.

Kiknadze, I. I. I Broshkov, A. D. 2009a. Kariotip i khromosomnyi polimorfizm u khironomid Chironomus melanescens Keyl, 1961 (Diptera, Chironomidae). - (The karyotype 
and chromosomal polymorphism of the midge Chironomus melanescens Keyl, 1961 (Diptera, Chironomidae). - Evraziat. ent. Zh. (= Euroas. ent. J.) 8, Suppl. 1: 19-28.

Kirilova, E., Heiri, O., Enters, D., Cremer, H., Lotter, A. F., Zolitschka, B. and Hübener, T. 2009a. Climate-induced changes in the trophic status of a Central European lake. - J. Limnol. 68: 71-82.

Klug, M., Schmidt, S., Bennike, O., Heiri, O., Melles, M. and Wagner, B. 2009a. Lake sediments from Store Koldewey, Northeast Greenland, as archive of Late Pleistocene and Holocene climatic and environmental changes. - Boreas 38: 59-71.

Koodalingam, A., Mullainadhan, P. and Arumugam, M. 2009a. Antimosquito activity of aqueous kernel extract of soapnut Sapindus emarginatus: impact on various developmental stages of three vector mosquito species and nontarget aquatic insects. Parasit. Res. 105: 1425-1434.

Koperski, P. 2009a. Reduced diversity and stability of chironomid assemblages (Chironomidae, Diptera) as the effect of moderate stream degradation. - Pol. J. Ecol. 57: 125-138.

Koszałka, J. 2009a. Chironomidae (Diptera) community response to improved oxygen conditions in a naturally recovering lake (Lękuk Wielki, northeast Poland). - Oceanol. hydrobiol. Stud. 38: 83-89.

Krasheninnikov, A. B. i Makarchenko, E. A. 2009a. Novye i maloizvestnyi vidy khironomid (Diptera, Chironomidae, Orthocladiinae) iz Visherskogo gosudarstvennogo prirodnogo zapovednika (Severnyi Ural). (New and little-known species of chironomids(Diptera, Chironomidae, Orthocladiinae) of the Vishersky Nature Reserve (North Ural).) Evraziat. ent. Zh. ( (= Euroas. ent. J.) 8, Suppl. 1: 97-101.

Krosch, M. N., Baker, A. M., McKie, B. G., Mather, P. B. and Cranston, P. S. 2009a. Deeply divergent mitochondrial lineages reveal patterns of local endemism in chironomids of the Australian Wet Tropics. Austral Ecol. 34: 317-328.

Kurek, J. and Cwynar, L. C. 2009a. Effects of within-lake gradients on the distribution of fossil chironomids from maar lakes in western Alaska: implications for environmental reconstructions. - Hydrobiologia 623: 37-52.
Kurek, J. and Cwynar, L. C. 2009b.The potential of site-specific and local chironomid-based inference models for reconstructing past lake levels. - J. Paleolimnol. 42: 37-50.

Kurek, J., Cwynar, L. C., Ager, T. A., Abbott, M. B. and Edwards, M. E. 2009a. Late Quaternary paleoclimate of western Alaska inferred from fossil chironomids and its relation to vegetation histories. - Quatern. Sci. Rev. 28: 799-811.

Kurek, J., Cwynar, L. C. and Vermaire, J. C. 2009a. A late Quaternary paleotemperature record from Hanging Lake, northern Yukon Territory, eastern Beringia. - Quatern. Res. 72: 246-257.

Kwan, J. A., Novak, M. G., Hyles, T. S. and Niemela, M. K. 2009a. Mortality of nontarget arthropods from an aerial application of pyrethrins. - J. Am. Mosquito Control Ass. 25: 218-220.

Lagauzère, S., Boyer, P., Stora, G. and Bonzom, J.-M. 2009a. Effects of uranium-contaminated sediments on the bioturbation activity of Chironomus riparius larvae (Insecta, Diptera) and Tubifex tubifex worms (Annelida, Tubificidae). - Chemosphere 76: 324-334.

Lagauzère, S., Pischedda, L., Cuny, P., Gilbert, F., Stora, G. and Bonzom, J.-M. 2009a. Influence of Chironomus riparius (Diptera, Chironomidae) and Tubifex tubifex (Annelida, Oligochaeta) on oxygen uptake by sediments. Consequences of uranium contamination. Envir. Pollut. 157: 1234-1242.

Lamentowicz, M., Balwierz, Z., Forysiak, J., Płóciennik, M., Kittel, P., Kloss, M., Twardy, J., Zurek, S. and Pawlyta, J. 2009a. Multiproxy study of anthropogenic and climatic changes in the last two millennia from a small mire in central Poland. Hydrobiologia 631: 213-230.

Langford, T. E. L., Shaw, P. J., Ferguson, A. J. D. and Howard, S. R. 2009a. Long-term recovery of macroinvertebrate biota in grossly polluted streams: Re-colonisation as a constraint to ecological quality. - Ecol. Indicators 9: 10641077.

Langton, P. H. 2009a. A structural hermaphrodite Micropsectra (DIPTERA: CHIRONOMIDAE). - In: Hughes, S. J., Khadem, M. and Carvalho, M. A. (eds.): Proc. $16^{\text {th }}$ Int. Chironomid Symp., Bolm Mus. munic. Funchal (Hist. nat.), Suppl. 13: 213216. 
Larocque, I., Grosjean, M., Heiri, O., Bigler, C. and Blass, A. 2009a. Comparison between chironomid-inferred July temperatures and meteorological data AD 1850-2001 from varved Lake Silvaplana, Switzerland. - J. Paleolimnol. 41: 329-342.

Larsen, S., Vaughan, I. P. and Ormerod, S. J. 2009a. Scale-dependent effects of fine sediments on temperate headwater invertebrates. - Freshwat. Biol. 54: 203-219.

Lau, D. C. P., Leung, K. M. Y. and Dudgeon, D. 2009a. What does stable isotope analysis reveal about trophic relationships and the relative importance of allochthonous and autochthonous resources in tropical streams? A synthetic study from Hong Kong. Freshwat. Biol. 54: 127.141.

Laufer, G., Arim, M., Loureiro, M., PiñeiroGuerra, J.M., Clavijo-Baquet, S. and Fagúndez, C. 2009a. Diet of four annual killifishes: An intra and interspecific comparison. - Neotrop. Ichthyol. 7: 77-86.

Lee, S.-W. and Choi, J. 2009a. Multi-level ecotoxicity assay on the aquatic midge, Chironomus tentans (Diptera, Chironomidae) exposed to octachlorostyrene. - Envir. Toxic. Pharmac. 28: 269-274.

Lee, S.-W., Kim, S.-M. and Choi, J. 2009a. Genotoxicity and ecotoxicity assays using the freshwater crustacean Daphnia magna and the larva of the aquatic midge Chironomus riparius to screen the ecological risks of nanoparticle exposure. - Envir. Toxic. Pharmac. 28: 86-91.

Lencioni, V., Boschini, D. and Rebecchi, L. 2009a. Expression of the $70 \mathrm{kDa}$ Heat shock protein family in Alpine freshwater chironomids (Diptera, Chironomidae) under natural conditions. - J. Limnol. 68: 251-256.

Lencioni, V., Marziali, L. and Rossaro, B. 2009a. Hyporheic chironomids in alpine streams. - In: Hughes, S. J., Khadem, M. and Carvalho, M. A. (eds.): Proc. $16^{\text {th }}$ Int. Chironomid Symp., Bolm Mus. munic. Funchal (Hist. nat.), Suppl. 13: 127-132.

León Paumen, M., de Voogt, P., van Gestel, C. A. M. and Kraak, M. H. S. 2009a. Comparative chronic toxicity of homo- and heterocyclic aromatic compounds to benthic and terrestrial invertebrates: Generalizations and exceptions. - Sci. tot. Envir. 407: 4605-4609.

Leonard, E. M., Pierce, L. M., Gillis, P. L., Wood, C. M. and O'Donnell, M. J. 2009a.
Cadmium transport by the gut and Malpighian tubules of Chironomus riparius. - Aquat. Toxic. 92: 179-186.

Li, A. O. Y., Ng, L. C. Y. and Dudgeon, D. 2009a. Effects of leaf toughness and nitrogen content on litter breakdown and macroinvertebrates in a tropical stream. Aquat. Sci. 71: 80-93.

Lobo-Rodrigues, J. J. 2009a. Taxonomia da fase adulta das espécies brasileiras de Goeldichironomus Fittkau, 1965 com redescrições de dez espécies e chave dicotômica (INSECTA: DIPTERA, CHIRONOMIDAE). - Tes. Mestr., Univ. Fed. Rio de Janeiro. 108 pp.

Ludlam, J. P. and Magoulick, D. D. 2009a. Spatial and temporal variation in the effects of fish and crayfish on benthic communities during stream drying. - J. N. Am. benthol. Soc. 28: 371-382.

Luoto, T. P. 2009a. Subfossil Chironomidae (Insecta: Diptera) along a latitudinal gradient in Finland: development of a new temperature inference model. - J. Quatern. Sci. 24: 150158.

Luoto, T. P. 2009b. A Finnish chironomid- and chaoborid-based inference model for reconstructing past lake levels. - Quatern. Sci. Rev. 28: 1481-1489.

Maasri, A., Fayolle, S. and Franquet, E. 2009a. Epilithic chironomid community structure: is it a matter of algae? - In: Hughes, S. J., Khadem, M. and Carvalho, M. A. (eds.): Proc. $16^{\text {th }}$ Int. Chironomid Symp., Bolm Mus. munic. Funchal (Hist. nat.), Suppl. 13: 133140.

MacDonald, G. M., Porinchu, D. F., Rolland, N., Kremenetsky, K. V. and Kaufman, D. S. 2009a. Paleolimnological evidence of the response of the central Canadian treeline zone to radiative forcing and hemispheric patterns of temperature change over the past 2000 years. - J. Paleolimnol. 41: 129-141.

Majumdar, T. N. and Gupta, A. 2009a. Acute toxicity of endosulfan and malathion on Chironomus ramosus (Insecta: Diptera: Chironomidae) from north Cachar hills, Assam, India. - J. envir. Biol. 30: 469-470.

Makarchenko, E. A. and Endo, K. 2009a. The description of immature stages of Linevitshia Makarchenko and Sasayusurika Makarchenko (Diptera, Chironomidae, Diamesinae), with some remarks on taxonomy and systematics 
of these genera. - Evraziat. ent. Zh. (= Euroas. ent. J.) 8, Suppl. 1: 64-70.

Makarchenko, E. A. i Makarchenko, M. A. 2009a.Novye nakhodki (Diptera, Chironomidae, Orthocladiinae) na Dal'nem Vostoke i sopredel'nykh territoriyakh. VII. Bryophaenocladius Thienemann. (New records of chironomids (Diptera, Chironomidae, Orthocladiinae) in Far East and bodering territories. VII. Bryophaenocladius Thienemann.) - Evraziat. ent. Zh. (= Euroas. ent. J.) 8, Suppl. 1: 51-63.

Makarchenko, E. A. i Makarchenko, M. A. 2009b. Pervye svedeniya po faune khironomid (Diptera, Chironomidae) basseina reki Langry (Severno-Zapadnyi Sakhalin). (First data on the chironomid fauna (Diptera, Chironomidae) of the Langry River Basin (North-West part of Sakhalin Island).) - Evraziat. ent. Zh. (= Euroas. ent. J.) 8, Suppl. 1: 71-77.

Makarchenko, E. A. and Makarchenko, M. A. 2009c. Prospilocerus amurensis sp. n. (Diptera, Chironomidae, Orthocladiinae) from Amur River basin (Russian Far East). Evraziat. ent. Zh. (= Euroas. ent. J.) 8: 261263.

Makarchenko, E. A. and Makarchenko, M. A. 2009d. New findings of chironomids (Diptera, Chironomidae) in Far East and bodering territories. IV. Subfamily Orthocladiinae. Evraziat. ent. Zh. (= Euroas. ent. J.) 8, Suppl. 1: $117-124$.

Makarchenko, E. A., Makarchenko, M. A. i Yavorskaya, N. M. 2009a. Novye nakhodki khironomid (Diptera, Chironomidae) na Dal'nem Vostoke i sopredel'nykh terrritoriyakh. VI. Hydrobaenus Fries. (New records of chironomids (Diptera, Chironomidae) in Far East and bordering territories. VI. Hydrobaenus Fries.) - Evraziat. ent. Zh. (= Euroas. ent. J.) 8, Suppl. 1: 33-50.

Marziali, L. 2009a. Benthic macroinvertebrates as water quality indicators in Italian lakes. - In: Hughes, S. J., Khadem, M. and Carvalho, M. A. (eds.): Proc. $16^{\text {th }}$ Int. Chironomid Symp., Bolm Mus. munic. Funchal (Hist. nat.), Suppl. 13: 51-59.

Masese, F. O., Muchiri, M. and Raburu, P. O. 2009a. Macroinvertebrate assemblages as biological indicators of water quality in the Moiben River, Kenya. - Afr. J. aquat. Sci. 34: 15-26.

Masese, F. O., Raburu, P. O. and Muchiri, M. 2009a. A preliminary benthic macroinvertebrate index of biotic integrity (BIBI) for monitoring the Moiben River, Lake Victoria Basin, Kenya. - Afr. J. aquat. Sci. 34: 1-14.

Massaferro, J., Donato, M. and Brooks, S. J. 2009a. New placement for Spaniotoma (Eukiefferiella) claviculata Edwards, 1931(Diptera: Chironomidae). - Zootaxa 2125: 67-68.

Massaferro, J. I., Moreno, P. I., Denton, G. H., Vandergoes, M. and Dieffenbacher-Krall, A. 2009a. Chironomid and pollen evidence for climate fluctuations during the Last Glacial Termination in NW Patagonia. - Quatern. Sci. Rev. 28: 517-525.

McGee, B. L., Pinkney, A. E., Velinsky, D. J., Ashley, J. T. F., Fisher, D. J., Ferrington, L. C. and Norberg-King, T. J. 2009a. Using the Sediment Quality Triad to characterize baseline conditions in the Anacostia River, Washington, DC, USA. - Envir. Monit. Assess. 156: 51-67.

McGoff, E. and Irvine, K. 2009a. A test of the association between Lake Habitat Quality Assessment and macroinvertebrate community structure. - Aquat. Conserv. mar. Freshwat. Ecosyst. 19: 520-533.

McLachlan, A. J. and Ladle, R. J. 2009a. The evolutionary ecology of detritus feeding in the larvae of freshwater Diptera. - Biol. Rev. 84: 133-141.

Meltser, N., Kashi, Y. and Broza, M. 2009a. Does polarized light guide chironomids to navigate toward water surfaces? - In: Hughes, S. J., Khadem, M. and Carvalho, M. A. (eds.): Proc. $16^{\text {th }}$ Int. Chironomid Symp., Bolm Mus. munic. Funchal (Hist. nat.), Suppl. 13: 141149.

Mendes, H. F. and Andersen, T. 2009a. Neotropical Nilothauma Kieffer, 1921, with the description of thirteen new species (Diptera: Chironomidae). - Zootaxa 2063: 145.

Michailova, P., Ilkova, J., Hankeln, T., Schmidt, E. R., Selvaggi, A., Zampicinini, G. and Sella, G. 2009a. Somatic breakpoints, distribution of repetitive DNA and non-LTR retrotransposon insertion sites in the chromosomes of Chironomus piger Strenzke (Diptera, Chironomidae). - Genetica 135: 137-148.

Michailova, P., Ilkova, J., Kerr, R. and White, K. 2009a. The effect of trace metals at acid and neutral conditions on the structure and 
function of polytene chromosomes in Chironomus species. - In: Hughes, S. J., Khadem, M. and Carvalho, M. A. (eds.): Proc. $16^{\text {th }}$ Int. Chironomid Symp., Bolm Mus. munic. Funchal (Hist. nat.), Suppl. 13: 61-68.

Michailova, P., Ilkova, J., Kerr, R. and White, K. 2009b. Chromosome variability in Chironomus acidophilus Keyl, 1960 from the Afon Goch, UK - a river subject to long-term trace metal pollution. - Aquat. Insects 31: 213225.

Michailova, P., Krastanov, B., Hankeln, T., Schmidt, E. and Kraemer, C. 2009a. In situ localization of the evolutionary conserved Cpy/Cty gene in the subfamily Chironominae (Chironomidae, Diptera): establishment of chromosomal homologies. - J. zool. Syst. evol. Res. 47: 298-301.

Michailova, P., Szarek-Gwiazda, E. and Kownacki, A. 2009a. Effect of contaminants on the genome of some species of genus Chironomus (Chironomidae, Diptera) live in sediments of Dunajec River and Czorsztyn Reservoir. - Wat. Air Soil Pollut. 202: 245258.

Michelutti, N., Keatley, B. E., Brimble, S., Blais, J. M., Liu, H., Douglas, M. S. V., Mallory, M. L., Macdonald, R. W. and Smol, J. P. 2009a. Seabird-driven shifts in Arctic pond ecosystems. - Proc. R. Soc. B 276: 591-596.

Mihaich, E. M., Friederich, U., Caspers, N., Hall, A. T., Klecka, G. M., Dimond, S. S., Staples, C. A., Ortego, L. S. and Hentges, S. G. 2009a. Acute and chronic toxicity testing of bisphenol A with aquatic invertebrates and plants. - Ecotoxic. envir. Saf. 72: 1392-1399.

Millet, L., Arnaud, F., Heiri, O., Magny, M., Verneaux, V. and Desmet, M. 2009a. LateHolocene summer temperature reconstruction from chironomid assemblages of Lake Anterne, northern French Alps. - Holocene 19: 317-328.

Miserendino, M. L. 2009a. Effects of flow regulation, basin characteristics and land-use on macroinvertebrate communities in a large arid Patagonian river. - Biodivers. Conserv. 18: 1921-1943.

Miyasaka, H. and Genkai-Kato, M. 2009a. Shift between carnivory and omnivory in stream stonefly predators. - Ecol. Res. 24: 11-19.

Moiseenko, T. I., Sharov, A. N., Vandish, O. I., Kudryavtseva, L. P., Gashkina, N. A. and Rose, C. 2009a. Long-term modification of
Arctic lake ecosystems: Reference condition, degradation under toxic impacts and recovery (case study Imandra Lakes, Russia). Limnologica 39: 1-13.

Moller Pillot, H. K. M. 2009a. Chironomidae larvae of the Netherlands and adjacent lowlands - Biology and ecology of the Chironomini. - KNNV Publ., Zeist. 270 pp.

Móra, A. 2009a. Faunistic particularities of the chironomid assemblages (Diptera: Chironomidae) of the Upper-Tisza, NE Hungary. - In: Hughes, S. J., Khadem, M. and Carvalho, M. A. (eds.): Proc. $16^{\text {th }}$ Int. Chironomid Symp., Bolm Mus. munic. Funchal (Hist. nat.), Suppl. 13: 5-12.

Muscatello, J. R. and Liber, K. 2009a. Accumulation and chronic toxicity of uranium over different life stages of the aquatic invertebrate Chironomus tentans. - Archs envir. Contam. Toxic. 57: 531-539.

Nalepa, T. F., Pothoven, S. A. and Fanslow, D. L. 2009a. Recent changes in benthic macroinvertebrate populations in Lake Huron and impact on the diet of lake whitefish (coregonus [sic!] clupeaformis). - Aquat. Ecosyst. Hlth Mgmt 12: 2-10.

Nardi, J. B., Miller, L. A., Bee, C. M., Lee Jr., R. E. and Denlinger, D. L. 2009a. The larval alimentary canal of the Antarctic insect, Belgica antarctica. - Arthropod Struct. Dev. 38: 377-389.

Neumann, D. and Woermann, D. 2009a. Physical conditions for trapping air by a microtrichiacovered insect cuticle during temporary submersion. - Naturwissenschaften 96: 933941.

Niitsuma, H. and Kato, H. 2009a. A synonymic note on Rheopelopia joganflava (Diptera, Chironomidae). - Jap. J. syst. Ent. 15: 255257.

Niitsuma, H. and Watson Jr, C. N. 2009a. Bilyjomyia, a new genus of the tribe Macropelopiini from the Holarctic (Diptera: Chironomidae). - Zootaxa 2166: 57-68.

Nin, C. S., Ruppenthal, E. L. e Rodrigues, G. G. 2009a. Produção de folhico e fauna associada de macroinvertebrados aquáticos em curso d'água de cabeceira em Floresta Ombrófila do Estado do Rio Grande do Sul, Brasil. - Acta Scient. biol. Sci. 31: 263-271.

Nogaro, G., Mermillod-Blondin, F., Valett, M. H., François-Carcaillet, F., Gaudet, J.-P., Lafont, M. and Gibert, J. 2009a. Ecosystem 
engineering at the sediment-water interface: bioturbation and consumer-substrate interaction. - Oecologia 161: 125-138.

Nowak, C., Vogt, C., Pfenninger, M., Schwenk, K., Oehlmann, J., Streit, B. and Oetken, M. 2009a. Rapid genetic erosion in pollutantexposed experimental chironomid populations. - Envir. Pollut. 157: 881-886.

Oberholster, P. J., Botha, A.-M. and Ashton, P. J. 2009a. The influence of a toxic cyanobacterial bloom and water hydrology on algal populations and macroinvertebrate abundance in the upper littoral zone of Lake Krugersdrift, South Africa. - Ecotoxicology 18: 34-46.

Obolewski, K. 2009a. Wykorzystanie makrozoobentosu do oceny stanu ekologicznego estuariowego jeziora Jamno. (Using macrozoobenthos to assess the ecological condition of the estuaryLake Jamno.) - Ochrona środ. 31: 17-24.

O'Brien, T. P., Roseman, E. F., Kiley, C. S. and Schaeffer, J. S. 2009a. Fall diet and bathymetric distribution of deepwater sculpin (Myoxocephalus thompsonii) in Lake Huron. J. Gt Lakes Res. 35: 464-472.

Olsson, K. and Nyström, P. 2009a. Noninteractive effects of habitat complexity and adult crayfish on survival and growth of juvenile crayfish (Pacifastacus leniusculus). Freshwat. Biol. 54: 35-46.

Orendt, C., Wolfram, G. and Schmitt-Jansen, M. 2009a. The chironomid communities (pupal exuviae) of groyne fields in a large lowland river in Central Europe (Elbe, Germany) and their potential use for ecotoxicological field studies. - In: Hughes, S. J., Khadem, M. and Carvalho, M. A. (eds.): Proc. 16 ${ }^{\text {th }}$ Int. Chironomid Symp., Bolm Mus. munic. Funchal (Hist. nat.), Suppl. 13: 69-75.

Padial, A. A., Thomaz, S. M. and Agostinho, A. A. 2009a. Effects of structural heterogeneity provided by the floating macrophyte Eichhornia azurea on the predation efficiency and habitat use of the small Neotropical fish Moenkhausia sanctaefilomenae.

Hydrobiologia 624: 161-170.

Park, H.-H. and Lee, J.-H. 2009a. Impact of pesticide treatment on an arthropod community in the Korean rice ecosystem. - J. Ecol. Field Biol. 32: 19-25.

Park, K. and Kwak, I.-S. 2009a. Alcohol dehydrogenase gene expression in Chironomus riparius exposed to $\mathrm{di}(2-$ ethylhexyl) phthalate. - Comp. Biochem. Physiol. Pt C 150: 361-367.

Park, K., Bang, H. W., Park, J. and Kwak, I.-S. 2009a. Ecotoxicological multilevel-evaluation of the effects of fenbendazole exposure to Chironomus riparius larvae. - Chemosphere 77: 359-367.

Park, S.-Y. and Choi, J. 2009a. Genotoxic effects of nonylphenol and bisphenol A exposure in aquatic biomonitoring species: freshwater crustacean, Daphnia magna, and aquatic midge, Chironomus riparius. - Bull. envir. Contam. Toxic. 83: 463-468.

Pedersen, M. L. and Friberg, N. 2009a. Influence of disturbance on habitats and biological communities in lowland streams. - Fundam. appl. Limnol. 174: 27-41.

Pepinelli, M., Siqueira, T., Salles, F. F. and Shimbori, E. M. 2009a. First report of Simuliidae and Chironomidae (Diptera) living on nymphs of Lachlania Hagen (Ephemeroptera: Oligoneuriidae) in South America. - Biota neotrop. 91, bn00509012009: 245-248.

Pestana, J. L. T., Alexander, A. C., Culp, J. M., Baird, D. J., Cessna, A. J. and Soares, A. M. V. M. 2009a. Structural and functional responses of benthic invertebrates to imidacloprid in outdoor stream mesocosms. Envir. Pollut. 157: 2328-2334.

Pestana, J. L. T., Loureiro, S., Baird, D. J. and Soares, A. M. V. M. 2009a. Fear and loathing in the benthos: Responses of aquatic insect larvae to the pesticide imidacloprid in the presence of chemical signals of predation risk. - Aquat. Toxic. 93: 138-149.

Pinho, L. C. de, Mendes, H. F. and Andersen, T. 2009a. A review of Skutzia Reiss, 1985, with the description of three new species (Diptera: Chironomidae: Chironominae). - J. N. Am. benthol. Soc. 28: 196-206.

Płóciennik, M. 2009a. Three species of Chironomidae (Diptera) new for the Polish fauna. - Lauterbornia 67 107-111.

Poi de Neiff, A., Galassi, M. E. and Franceschini, M. C. 2009a. Invertebrate assemblages associated with leaf litter in three floodplain wetlands of the Paraná River. - Wetlands 29: 896-906.

Polukonova, N. V., Djomin, A. G., Mugue, N. S. i Shaikevich, E. V. 2009a. Sravnenie Chironomus usenicus i Ch. curabilis s vidami gruppy plumosus (Diptera) po genu 
mitokhondrial'noi DNK COI i risunku diskov politennykh khromosom. (Comparison of Chironomus usenicus and Chironomus curabilis with species of the group plumosus (Diptera) inferred from the mitochondrial DNA gene COI and by the polytene chromosome banding pattern.) - Genetika 45: 1029-1035. [also published as: Russ. J. Genet. 45: 899-905.]

Porinchu, D. F., MacDonald, G. M. and Rolland, N. 2009a. A 2000 year midge-based paleotemperature reconstruction from the Canadian Arctic archipelago. - J. Paleolimnol. 41: 177-188.

Porinchu, D., Rolland, N. and Moser, K. 2009a. Development of a chironomid-based air temperature inference model for the central Canadian Arctic. - J. Paleolimnol. 41: 349368.

Porst, G. and Irvine, K. 2009a. Distinctiveness of macroinvertebrate communities in turloughs (temporary ponds) and their response to environmental variables. - Aquat. Conserv. mar. Freshwat. Ecosyst. 19: 456-465.

Pothoven, S. A., Vanderploeg, H. A., Ludsin, S. A., Höök, T. O. and Brandt, S. B. 2009a. Feeding ecology of emerald shiners and rainbow smelt in central Lake Erie. - J. Gt Lakes Res. 35: 190-198.

Power, M., Lowe, R., Furey, P., Welter, J., Limm, M., Finlay, J., Bode, C., Chang, S., Goodrich, M. and Sculley, J. 2009a. Algal mats and insect emergence in rivers under Mediterranean climates: towards photogrammetric surveillance. - Freshwat. Biol. 54: 2101-2115.

Pramual, P., Gomontean, B., Buasay, V., Srikhamwiang, N., Suebkar, P., Niamlek, C., Donsinphoem, Y. and Chalat-Chieo, K. 2009a. Population cytogenetics of Chironomus circumdatus Kieffer, 1921 (Diptera, Chironomidae) from Thailand. Genetica 135: 51-57.

Proviz, V. I. 2009a. Kariotip i khromosmnyi polimorfizm Chironomus solitus Linevitch et Erbaeva, 1971 (Diptera, Chironomidae) iz Irkutskogo vodokhranilishcha. (The karyotype and chromosomal polymorphism of Chironomus solitus Linevitsh et Erbaeva, 1971 (Diptera, Chironomidae) from the Irkutsk Reservoir.) - Evraziat. ent. Zh. (= Euroas. ent. J.) 8, Suppl. 1: 15-18.

Proviz, V. I., Bel'kov, V. M., Proviz, L. I. i Aleksandrov, V. N. 2009a. Kariotip i morfologiya Chironmus nigrifrons Linevitsh et Erbaeva, 1971 (Diptera, Chironomidae) iz Irkutskogo vodokhranilishcha. (The karyotype asnd morphology of Chironmus nigrifrons Linevitsh et Erbaeva, 1971 (Diptera, Chironomidae) from the Irkutsk Reservoir. Evraziat. ent. Zh. (= Euroas. ent. J.) 8, Suppl. 1: 6-14.

Prus, P. 2009a. The dependencies between the abundance of Chironomus f. l. plumosus and bream (Abramis brama) net catches in a lowland reservoir (Zegrzyński Reservoir, central Poland). - Oceanol. hydrobiol. Stud. 38: $15-30$

Puntí, T., Rieradevall, M. and Prat, N. 2009a. Environmental factors, spatial variation, and specific requirements of Chironomidae in Mediterranean reference streams. - J. N. Am. benthol. Soc. 28: 247-265.

Qi, X., Shi, S.-D. and Wang, X.-H. 2009a. A review of Paratendipes Kieffer from China (Diptera: Chironomidae). - Aquat. Insects 31: 63-70.

Ramseyer, U. and Marchese, M. 2009a. Leaf litter of Erythrina crista-galli L. (ceibo): trophic and substratum resources for benthic invertebrates in a secondary channel of the Middle Parana River. - Limnetica 28: 1-10.

Raposeiro, P. M., Hughes, S. J. and Costa, A. C. 2009a. Chironomidae (Diptera: Insecta) in Oceanic islands: New records for the Azores and biogeographic notes. - Annls Limnol. 45: 59-67.

Rasic, G., Maxwell, S. A. and Keyghobadi, N. 2009a. Characterization of microsatellite loci for the pitcher plant midge, Metriocnemus knabi Coq. (Diptera: Chironomidae). - Molec. Ecol. Resourc. 9: 1388-1391.

Rawani, A., Haldar, K. M., Ghosh, A. and Chandra, G. 2009a. Larvicidal activities of three plants against filarial vector Culex quinquefasciatus Say (Diptera: Culicidae). Parasit. Res. 105: 1411-1417.

Rehn, A. C. 2009a. Benthic macroinvertebrates as indicators of biological condition below hydropower dams on west slope Sierra Nevada streams, California, USA. - River Res. Applics 25: 208-228.

Reinemann, S. A., Porinchu, D. F., Bloom, A. M., Mark, B. G. and Box, J. E. 2009a. A multiproxy paleolimnological reconstruction of Holocene climate conditions in the Great 
Basin, United States. - Quatern. Res. 72: 347358.

Riley, W. D., Pawson, M. G., Quayle, V. and Ives, M. J. 2009a. The effects of stream canopy management on macroinvertebrate communities and juvenile salmonid production in a chalk stream. - Fish. Mgmt Ecol. 16: 100-111.

Rodrigues, G. G., Langton, P. H. and Scharf, B. W. 2009a. The pupal exuviae of Chironomus crassimanus Strenzke (Diptera: Chironomidae), an acid-resistant species from Germany. - Zootaxa 2026: 47-52.

Rolland, N., Larocque, I., Francus, P., Pienitz, R. and Laperrière, L. 2009a. Evidence for a warmer period during the 12th and 13th centuries AD from chironomid assemblages in Southampton Island, Nunavut, Canada. Quatern. Res. 72: 27-37.

Rolland, N., Porinchu, D. F. and Larocque, I. 2009a. The use of high-resolution gridded climate data in the development of chironomid-based inference models from remote areas. - J. Paleolimnol. 41: 343-348.

Rufer, M. M. and Ferrington Jr., L. C. 2009a. Sampling frequency required for chironomid community resolution in urban lakes with contrasting trophic states. - In: Hughes, S. J., Khadem, M. and Carvalho, M. A. (eds.): Proc. $16^{\text {th }}$ Int. Chironomid Symp., Bolm Mus. munic. Funchal (Hist. nat.), Suppl. 13: 77-84.

Rundio, D. E. 2009a. Community-habitat relationships in coastal streams in Big Sur, California, USA: travertine influences macroinvertebrate abundance and community structure. - Hydrobiologia 620: 91-108.

Sæther, O. A. 2009a. Telmatogeton murrayi sp. n. from Iceland and T. japonicus Tokunaga from Madeira (Diptera: Chironomidae). - Aquat. Insects 31: 31-44.

Sæther, O. A. 2009b. Cryptochironomus Kieffer from Lake Winnipeg, Canada, with a review of Nearctic species (Diptera: Chironomidae). Zootaxa 2208: 1-24.

Sánchez-Argüello, P., Fernández, C. and Tarazona, J. V. 2009a. Assessing the effects of fluoxetine on Physa acuta (Gastropoda, Pulmonata) and Chironomus riparius (Insecta, Diptera) using a two-species water-sediment test. - Sci. tot. Envir. 407: 1937-1946.

Sandin, L. 2009a. The effects of catchment landuse, near-stream vegetation, and river hydromorphology on benthic macroinvertebrate communities in a southSwedish catchment. - Fundam. appl. Limnol. 174: 75-87.

Schabetsberger, R., Luger, M. S., Drozdowski, G. and Jagsch, A. 2009a. Only the small survive: monitoring long-term changes in the zooplankton community of an Alpine lake after fish introduction. - Biol. Invasions 11: 1335-1345.

Schlief, J. and Mutz, M. 2009a. Effect of sudden flow reduction on the decomposition of alder leaves (Alnus glutinosa [L.] Gaertn.) in a temperate lowland stream: a mesocosm study. - Hydrobiologia 624: 205-217.

Schmidl, J., Sulzer, P. and Kitching, R. L. 2009a. The insect assemblage in water filled treeholes in a European temperate deciduous forest: community composition reflects structural, trophic and physicochemical factors. - Hydrobiologia 598: 285-303.

Schuler, L. J., Landrum, P. F., Harwood, A. D., Tripp, E. M. and Lydy, M. J. 2009a. Joint toxicity of fluoranthene and pentachlorobenzene to Hyalella azteca and Chironomus dilutus. - Chemosphere 77: 399403.

Scott, J. J., Renaut, R. W., Buatois, L. A. and Owen, R. B. 2009a. Biogenic structures in exhumed surfaces around saline lakes: An example from Lake Bogoria, Kenya Rift Valley. - Palaeogeogr. Palaeoclim. Palaeoecol. 272: 176-198.

Sealock, A. W. and Ferrington Jr., L. C. 2009a. Sampling efficiency of Chironomidae (Diptera) across disturbance gradients. - In: Hughes, S. J., Khadem, M. and Carvalho, M. A. (eds.): Proc. $16^{\text {th }}$ Int. Chironomid Symp., Bolm Mus. munic. Funchal (Hist. nat.), Suppl. 13: 85-92.

Sergeeva, I. V. and Anikina, M. A. 2009a. (Midges of the subfamily Tanypodinae (Diptera, Chironomidae) of Russia: Tribes Coelotanypodini Kieffer, 1913 and Tanypodini Meigen, 1803.) - Ent. Oboz. 88: 177-184. [also published as: Ent. Rev. 89: 213-217.]

Sherk, T. and Rau, G. H. 2009a. Emergence of Ablabesmyia monilis (Diptera: Chironomidae) from Findley Lake during warm and cold years. - In: Hughes, S. J., Khadem, M. and Carvalho, M. A. (eds.): Proc. $16^{\text {th }}$ Int. Chironomid Symp., Bolm Mus. munic. Funchal (Hist. nat.), Suppl. 13: 199-205. 
Silver, P., Rupprecht, S. M. and Stauffer, M. F. 2009a. Temperature-dependent effects of road deicing salt on chironomid larvae. - Wetlands 29: 942-951.

Skoulikidis, N. T., Karaouzas, I. and Gritzalis, K. C. 2009a. Identifying key environmental variables structuring benthic fauna for establishing a biotic typology for Greek running waters. - Limnologica 39: 565-66.

Smith, B. J., Davies, P. E. and Munks, S. A. 2009a. Changes in benthic macroinvertebrate communities in upper catchment streams across a gradient of catchment forest operation history. - For. Ecol. Mgmt 257: 2166-2174.

Sommer, B. and Horwitz, P. 2009a. Macroinvertebrate cycles of decline and recovery in Swan Coastal Plain (Western Australia) wetlands affected by droughtinduced acidification. - Hydrobiologia 624: 191-203.

Sonoda, K. C., Matthaei, C. D. and TrivinhoStrixino, S. 2009a. Contrasting land uses affect Chironomidae communities in two Brazilian rivers. - Fundam. appl. Limnol. 174: 173-184.

Spies, M., Andersen, T., Epler, J. H. and Watson Jr, C. N. 2009a. Chironomidae (non-biting midges). - In: Brown, B. V., Borkent, A., Cumming, J. M., Wood, D. M., Woodley, N. E. and Zumbado, M. (eds.): Manual of Central American Diptera, vol. 1: 437-480. NRC Pr., Ottawa.

Specziár, A. and Rezsu, E. T. 2009a. Feeding guilds and food resource partitioning in a lake fish assemblage: an ontogenetic approach. - $J$. Fish Biol. 75: 247-267.

Stief, P., Poulsen, M., Nielsen, L. P., Brix, H. and Schramm, A. 2009a. Nitrous oxide emission by aquatic macrofauna. - Proc. natn. Acad. Sci. U. S. A. 106: 4296-4300.

Stubbington, R., Greenwood, A. M., Wood, P. J., Armitage, P. D., Gunn, J. and Robertson, A. L. 2009a. The response of perennial and temporary headwater stream invertebrate communities to hydrological extremes. Hydrobiologia 630: 299-312.

Sun, X.-B., Wang, S.-T. and Cui, F.-Y. 2009a. (Effects of chlorine dioxide on the inactivation of the chironomid larvae.) Zhongguo Huanjing Kexue (China envir. Sci.) 29: 617-621.
Syrovátka, V. and Brabec, K. 2009a. The response of chironomid larvae to hydraulic conditions: Synorthocladius semivirens (DIPTERA: CHIRONOMIDAE) in two different rivers. - In: Hughes, S. J., Khadem, M. and Carvalho, M. A. (eds.): Proc. $16^{\text {th }}$ Int. Chironomid Symp., Bolm Mus. munic. Funchal (Hist. nat.), Suppl. 13: 161-167.

Syrovátka, V., Schenková, J. and Brabec, K. 2009a. The distribution of chironomid larvae and oligochaetes within a stony-bottomed river stretch: the role of substrate and hydraulic conditions. - Fundam. appl. Limnol. 174: 43-62.

Taber, S. W. 2009a. A new species of Polypedilum Kieffer midge (Diptera: Chironomidae). - SWest. Ent. 34: 245-261.

Takamura, N., Ito, T., Ueno, R., Ohtaka, A., Wakana, I., Nakagawa, M., Ueno, Y. and Nakajima, H. 2009a. Environmental gradients determining the distribution of benthic macroinvertebrates in Lake Takkobu, Kushiro wetland, northern Japan. - Ecol. Res. 24: 371381.

Tanikawa, T., Inoue, E. and Hirabayashi, K. 2009a. (Limnophyes natalensis (Kieffer, 1914) (Diptera: Chironomidae) breeding in indoor sewage.) - Pestology 24. 15-17.

Taşdemir, A., Ustaoğlu, M. R. ve Balık, S. 2009a. Gediz Deltası (Menemen-İzmir) Chironomidae (Diptera) Faunası'na Katkılar. (Contributions to the knowledge of Chironomidae (Diptera) fauna of the Gediz Delta (Menemen-İzmir-Turkey).) - J. Fish. Sci.com 3: 32-39.

Tassou, K. T. and Schulz, R. 2009a. Effects of the insect growth regulator pyriproxyfen in a twogeneration test with Chironomus riparius. Ecotoxic. envir. Saf. 72: 1058-1062.

Tejerina, E. G. and Paggi, A. C. 2009a. A new Neotropical species of Oliveiriella Wiedenbrug \& Fittkau (Diptera: Chironomidae) from Argentina, with description of all its life stages. - Aquat. Insects 31: 91-98.

Tellioglu, A. and Kara, T. 2009a. Seasonal abundance of Chironomidae larvae (Diptera) in Büyük Stream, Elaziğ, Turkey. - $J$. Freshwat. Ecol. 24: 169-171.

Timms, B. V. 2009a. A study of the salt lakes and salt springs of Eyre Peninsula, South Australia. - Hydrobiologia 626: 41-51. (+ Electr. Suppl. Mat.) 
Tixier, G., Wilson, K. P. and Williams, D. D. 2009a. Exploration of the influence of global warming on the chironomid community in a manipulated shallow groundwater system. Hydrobiologia 624: 13-27.

Tóth, M., Móra, A., Kiss, B. and Dévai, Gy. 2009a. Chironomid communities in different vegetation types in a backwater Nagy-morotva of the active floodplain of River Tisza, Hungary - In: Hughes, S. J., Khadem, M. and Carvalho, M. A. (eds.): Proc. $16^{\text {th }}$ Int. Chironomid Symp., Bolm Mus. munic. Funchal (Hist. nat.), Suppl. 13: 169-175.

Townsend, K. R., Pettigrove, V. J., Carew, M. E. and Hoffmann, A. A. 2009a. The effects of sediment quality on benthic macroinvertebrates in the River Murray, Australia. - Mar. Freshwat. Res. 60: 70-82.

Travina, T. N. i Vvedenskaya, T. L. 2009a. Rol' khironomid (Diptera, Chironomidae) v pitanii molodi lososei i drugikh vidov ryb $\mathrm{v}$ reke Bolshaya. (Chironomids (Diptera, Chironomidae) in the diet of juvenile salmon and other fish in the Bolshaya River (West Kamchatka).) - Evraziat. ent. Zh. (= Euroas. ent. J.) 8, Suppl. 1: 102-108.

Trigal, C., García-Criado, F. and FernándezAláez, C. 2009a. Towards a multimetric index for ecological assessment of Mediterranean flatland ponds: the use of macroinvertebrates as bioindicators. - Hydrobiologia 618: 109123.

Trivinho-Strixino, S. and Strixino, G. 2009a. A new species of Pelomus Reiss, 1989 (DIPTERA: CHIRONOMIDAE) from Southeastern Brazil, with the description of immature stages. - In: Hughes, S. J., Khadem, M. and Carvalho, M. A. (eds.): Proc. $16^{\text {th }}$ Int. Chironomid Symp., Bolm Mus. munic. Funchal (Hist. nat.), Suppl. 13: 217-225.

Tullos, D. D., Penrose, D. L., Jennings, G. D. and Cope, W. G. 2009a. Analysis of functional traits in reconfigured channels: implications for the bioassessment and disturbance of river restoration. - J. N. Am. benthol. Soc. 28: 8092.

Tyagi, A., Ryme, J., Brodin, D., Östlund Farrants, A. K. and Visa, N. 2009a. SWI/SNF associates with nascent pre-mRNPs and regulates alternative pre-mRNA processing. PLoS Genet. 5, 5, e1000470: 15 pp.

Utz, R. M., Hilderbrand, R. H. and Boward, D. M. 2009a. Identifying regional differences in threshold responses of aquatic invertebrates to land cover gradients. - Ecol. Indicators 9: 556-567.

Uzarski, D. G., Burton, T. M., Kolar, R. E. and Cooper, M. J. 2009a. The ecological impacts of fragmentation and vegetation removal in Lake Huron's coastal wetlands. - Aquat. Ecosyst. Hlth Mgmt 12: 45-62.

Vallenduuk, H. 2009a. Larvae of the Tanypodinae (Diptera: Chironomidae): New (neglected) characters and the making of a new key. - Proc. Neth. ent. Soc. Meet. 20: 5566.

Varadinova, E., Pehlivanov, L., Moskova, G. and Uzunov, Y. 2009a. Development and actual state of the macrozoobenthic fauna in the Srebarna Biosphere Reserve (north-east Bulgaria). - C. r. Acad. Bulg. Sci. 62: 243-248.

Vedamanikam, V. J. 2009a. Formation of resistance in the Chironomus plumosus to four pesticides over 45 generations. - Toxic. envir. Chem. 91: 187-194.

Vedamanikam, V. J. and Shazili, N. A. M. 2009a. Observations of mouthpart deformities in the Chironomus larvae exposed to different concentrations of nine heavy metals. - Toxic. envir. Chem. 91: 57-63.

Vedamanikam, V. J. and Shazili, N. A. M. 2009b. Comparative toxicity of nine metals to two Malaysian aquatic dipterian larvae with reference to sediment composition. - Toxic. envir. Chem. 91: 129-136.

Vedamanikam, V. J. and Shazili, N. A. M. 2009c. The chironomid larval tube, a mechanism to protect the organism from environmental disturbances? - Toxic. envir. Chem. 91: 171176.

Vink, J. P. M. 2009a. The origin of speciation: Trace metal kinetics over natural water/sediment interfaces and the consequences for bioaccumulation. - Envir. Pollut. 157: 519-527.

Vinogradova, E. M., Riss, H. W. and Spies, M. 2009a. New species of Tanytarsus van der Wulp, 1874 (Diptera: Chironomidae) from Central America. - Aquat. Insects 31: 11-17.

Virtanen, R., Ilmonen, J., Paasivirta, L. and Muotka, T. 2009a. Community concordance between bryophyte and insect assemblages in boreal springs: a broad-scale study in isolated habitats. - Freshwat. Biol. 54: 1651-1662. 
Vonesh, J. R. and Kraus, J. M. 2009a. Pesticide alters habitat selection and aquatic community composition. - Oecologia 160: 379-385.

Vonesh, J. R., Kraus, J. M., Rosenberg, J. S. and Chase, J. M. 2009a. Predator effects on aquatic community assembly: disentangling the roles of habitat selection and postcolonization processes. - Oikos 118: 12191229.

Wang, Y. V., O'Brien, D. M., Jenson, J., Francis, D. and Wooller, M. J. 2009a. The influence of diet and water on the stable oxygen and hydrogen isotope composition of Chironomidae (Diptera) with paleoecological implications. - Oecologia 160: 225-233.

Weston, D. P., Lentz, R. D., Cahn, M. D., Ogle, R. S., Rothert, A. K. and Lydy, M. J. 2009a. Toxicity of anionic polyacrylamide formulations when used for erosion control in agriculture. - J. envir. Qual. 38: 238-247.

Wiedenbrug, S. and Trivinho-Strixino, S. 2009a. Ubatubaneura, a new genus of the Corynoneura group (Diptera: Chironomidae: Orthocladiinae) from the Brazilian Atlantic Forest. - Zootaxa 1993: 41-52.

Wiedenbrug, S., Mendes, H. F., Pepinelli, M. and Trivinho-Strixino, S. 2009a. Review of the genus Onconeura Andersen et Sæther (Diptera: Chironomidae), with the description of four new species from Brazil. - Zootaxa 2265: 1-26.

Wijngaarden, R. P. A. van, Barber, I. and Brock, T. C. M. 2009a. Effects of pyrethroid insecticide gamma-cyhalothrin on aquatic invertebrates in laboratory and outdoor microcosm tests. - Ecotoxicology 18: 211-224.

Williams, M., Cook, E., van der Kaars, S., Barrows, T., Shulmeister, J. and Kershaw, P. 2009a. Glacial and deglacial climatic patterns in Australia and surrounding regions from 35 000 to 10000 years ago reconstructed from terrestrial and near-shore proxy data. Quatern. Sci. Rev. 28: 2398-2419.

Wissinger, S. A., Greig, H. and McIntosh, A. 2009a. Absence of species replacements between permanent and temporary lentic communities in New Zealand. - J. N. Am. benthol. Soc. 28: 12-23.

Wright, I. A. and Burgin, S. 2009a. Effects of organic and heavy metal pollution on chironomids within a pristine upland catchment. - Hydrobiologia 635: 15-25.
Wuelker, W., Martin, J., Kiknadze, I. I., Sublette, J. E. and Michiels, S. 2009a. Chironomus blaylocki sp. n. and C. bifurcatus sp. n., North American species near the base of the decorus-group (Diptera: Chironomidae). Zootaxa 2023: 28-46.

Yang, Y., Hunter, W., Tao, S. and Gan, J. 2009a. Effects of black carbon on pyrethroid availability in sediment. - J. agric. Food Chem. 57: 232-238.

Yasué, M. and Dearden, P. 2009a. The importance of supratidal habitats for wintering shorebirds and the potential impacts of shrimp aquaculture. - Envir. Mgmt 43: 1108-1121.

Yavorskaya, N. M. i Makarchenko, M. A. 2009a. Pervye svedeniya po faune khironomid (Diptera, Chironomidae) Bol'shekhekhtsirskogo gosudarstvennogo prirodnogo zapovednika (Khabarovskii krai). (First data on the chironomid fauna (Diptera, Chironomidae) of the Bolshekhekhtsirski nature Reserve (Khabarovsk Territory).) Evraziat. ent. Zh. (= Euroas. ent. J.) 8, Suppl. 1: 93-96.

Yoshimi, T., Odagiri, K., Hiroshige, Y., Yokobori, S.-i., Takahashi, Y., Sugaya, Y. and Miura, T. 2009a. Induction profile of HSP70cognate genes by environmental pollutants in Chironomidae. - Envir. Toxic. Pharmac. 28: 294-301.

Zelentsov, N. I. 2009a. Fauna khironomid (Dipterra, Chironomidae) Khibinskikh ozer Kol'skogo poluostrova. (The chironomid fauna (Diptera, Chironomidae) of the Khibiny's lakes of Kola Pensinsula.) Evraziat. ent. Zh. (= Euroas. ent. J.) 8, Suppl. 1: 89-92.

Zinchenko, T. D., Makarchenko, M. A. i Makarchenko, E. A. 2009a. Novyi vid roda Cricotopus van der Wulp (Diptera, Chironomidae) iz solenoi reki basseina ozera El'ton (Volgogradskaya oblast', Rossiya). (A new species of Cricotopus van der Wulp (Diptera, Chironomidae) from a saline river of the El'ton Lake basin (Volgograd Region, Russia). - Evraziat. ent. Zh. (= Euroas. ent. J.) 8, Suppl. 1: 83-88.

Zorina, O. V. 2009a. Synendotendipes shanduyensis sp. n. (Diptera, Chironomidae, Chironominae) from elevated lakes of Sikhote-Alin' Biosphere Nature Reserve. Evraziat. ent. Zh. (= Euroas. ent. J.) 8, Suppl. 1: 78-82. 
Zorina, O. V. i Zinchenko, T. D. 2009a. Novyi vid roda Tanytarsus van der Wulp(Diptera, Chironomidae) iz solenoi reki basseina reki El'ton (Volgogradskaya oblast', Rossiya). (A new species of Tanytarsus van der Wulp (Diptera, Chironomidae) from a saline river of the El'ton Lake basin (Volgograd Region, Russia). - Evraziat. ent. Zh. (= Euroas. ent. J.) 8, Suppl. 1: 105-110.

Abstracts from the XVIIth International Symposium on Chironomidae in Nankai University, Tianjin, China, 2009 (sequence in abstracts book, Wang, X.-H., ed.))

\section{A. Oral presentations:}

Martin, J. 2009a. From bands to base pairs: Problems in the identification of Chironomus species, using the example of Chironomus oppositus Walker. - 11.

Al-Shami, S. A., Che Salmahi, M. R., Siti Azizah, M. N. and.Abu Hassan, A 2009b. Distribution of Chironomidae (Diptera) under the influence of several environmental parameters in polluted rivers of Juru River Basin, Penang, Malaysia. - 12.

Anderson, A. M., Bouchard, R. W. and Ferrington, L. C. 2009a. Hibernal emergence of Chironomidae in relation to stream size in Kansas. - 13.

Ashe, P. and O’Connor, J. P. 2009a. Part 1 of a world catalogue of Chironomidae (Diptera). 14.

Brabec, K., Jarkovsky, J. and Kubosova, K. 2009a. Occurrence and co-occurrence of stream chironomids: associations with environmental gradients and community characteristics. - 15.

Chon, T., Tang, H., Qu, X., Bae, M., Song, M. and Park, Y. 2009a. Community structure and species abundance distribution in chironomids collected in streams in different pollution levels. - 16.

Ebrahimnezhad, M. and Allahbakhshi, E. 2009a. Chironomidae (Diptera) genera from Golpayegan River, Iran. - 17.

Ekrem, T., Willassen, E. and Stur, E. 2009a. Molecular phylogeny of Micropsectra and allies: indications of new generic synonyms (Diptera: Chironomidae): - 18-19.

Ermolaeva, O. 2009b. Comparative karyological analysis of the subfamily Diamesinae (Diptera, Chironomidae). - 20.
Ferrington Jr., L. C., Westrick, M. and Karns, B. 2009a. Alpha, beta and gamma diversities of Chironomidae emergence from 20 spring-runs in the Saint Croix River basin, Minnesota. 21-22.

Golygina, V. V., Istomina, A. G. and Kiknadze, I. I. 2009a. Interspecific hybridization between sibling species of Chironomus plumosus group (Diptera: Chironomidae). - 23-24.

Gresens, S. E. 2009a. Response of Chironomidae to multiple gradients of urban impact. - 25.

Gunderina, L. I. and Katokhin, A. V. 2009a. Variation and divergence of rDNA ITS-1 region in species of genus Chironomus (Diptera: Chironomidae). - 26-27.

Inoue, E., Tsukada, M. and Hirabayashi, K. 2009a. Structural analyses of silk and nesting tubes of chironomid larvae (Diptera). - 28.

Kiknadze, I. and Istomina, A. 2009a. Karyological study of Chironomus species from the Netherlands. - 29-30.

Kaga, K., Kasuya, S., Kobayashi, T. and Ohtaka, A. 2009a. Identification of chironomid species by DNA sequence - especially genus Hydrobaenus including $H$. sp. Tsugaru. - 31.

Kobayashi, T., Ohtaka, A., Kasuya, S. and Kaga, K. 2009a. Hydrobaenus sp. Tsugaru with extremely short male antennae from Tsugaru Peninsula, northern Japan (Diptera: Chironomidae). - 32-33.

Langton, P. H. 2009a. Pupal exuviae structure further elaborated. - 34.

Lencioni, V., Marziali, L. and Rossaro, B. 2009b. Diversity and distribution of chironomids in natural and impacted springs in the Italian Prealps and Alps. - 35.

Liu, Y., Ji, C. and Chon, T. 2009a. Automatic detection of response behaviors of Chironomus riparius after exposure to toxic chemicals by using computational methods. 36.

Makarchenko, E. A. and Makarchenko, M. A. 2009e. Fauna and taxonomy of the Orthocladiinae (Diptera: Chironomidae) of the Russian Far East. - 37.

Marziali, L., Rossaro, B. and Buffagni, A. 2009a. Temporal and spatial variability of chironomid assemblages in a large lowland river (Po River, Northern Italy). - 38-39.

Rossaro, B., Marziali, L., Boggero, A. and Lencioni, V. 2009a. Benthic 
macroinvertebrates

(Chironomidae, Oligochaeta) in Italian lakes. - 40-41.

McBean, J. E. 2009a. Microtendipes Kieffer prohumeral reversed setae - gratis mutation or functional asset? - 42.

McBean, S. F. 2009a. Questioning feeding related factors in niche separation in chironomid larvae, in particular mentum profile of Orthocladiinae and Chironominae. - 43.

Nath, B. B. and Babrekar, A. A. 2009a. Implications of hypoxic stress in Chironomus ramosus larvae with reference to iron. - 44.

Przhiboro, A. and Sæther, O. A. 2009a. Littoral chironomid communities of two small lakes in Northern Karelia (Russia) studied by emergence traps: species composition and changes over a 30-years period. - 45-46.

Stur, E. and Ekrem, T. 2009a. Exploring unknown life stages of Arctic Chironomidae (Diptera) with DNA barcoding. - 47.

Yamamoto, M. and Yamamoto, N. 2009a. A review of Yaeprimus isigaabeus Sasa \& Susuki, 2000 (Diptera: Chironomidae). - 48.

Yamamoto, N., Hirowatari, T. and and Yamamoto, M. 2009a.The subgenus Pentapedilum of the genus Polypedilum (Diptera: Chironomidae) in Iriomote Island, the Ryukyus, Japan. - 49.

B. Poster presentations:

Ali, A., Leckel Jr., R. J. and Duxbury, C. V. 2009a. Chironomidae investigations in selected Florida wetlands . - 51-52.

Andersen, T., Mendes, H. F., Pinho, L. C., Roque, F. O. and Spies, M. 2009a. An updated checklist of Brazilian Chironomidae (Diptera). 53-54.

Ashe, P. 2009a. A bibliography, with dates of publication, of J. J. Kieffer's publications on Chironomidae (Diptera). - 55.

Caldwell, B. A. 2009b. A novel pupa of Pseudorthocladius Goetghebuer, new Nearctic record for Doithrix villosa Sæther \& Sublette, and variation in Doithrix dillonae Cranston \& Oliver (Diptera: Chironomidae). 56.

Cheng, M. and Wang, X. 2009b. Ablabesmyia Johannsen (Diptera: Chironomidae: Tanypodinae) from China. - 57.

Przhiboro, A., Ekrem, T. and Stur, E. 2009a. Bionomics and taxonomy of Tanytarsus recurvatus Brundin, 1947. - 58.
Ermolaeva, O. 2009c. Comparative karyological analysis of the subfamily Prodiamesinae (Diptera, Chironomidae). - 59.

Fu, Y., Andersen, T. and Mendes, H. F. 2009a. Paratrichocladius Santos Abreu from Patagonia (Diptera: Chironomidae: Orthocladiinae). - 60.

Fu. Z., Inoue, E., K. Yoshizawa, K., Yoshida, N., Kazama, F. and K.Hirabayashi, K. 2009a. Horizontal distribution of chironomid larvae (Diptera) in Lake Saiko, Japan. - 61.

Grzybkowska, M. and Głowacki, Ł. 2009a. Chironomidae (Diptera) diversity in lowland rivers of different orders in central Poland. 62.

Hirabayashi, K., Yoshizawa, K., Oga, K., Yoshida, N., Ariizumi, K. and Azama, F. K. 2009a. Population dynamics of benthic macroinvertebrates in a eutrophic-mesotrophic lake, Lake Kawaguchi, Japan. - 63-64.

Hu, Y. 2009a. A case study for effects of bt rice on non-biting midges in paddy field. - 65.

Ikutama, E., Inoue, E. and Hirabayashi, K. 2009a. Density dynamics of chironomid larvae (Diptera) in the middle reaches of the Shinano River, Japan: the response to floods. - 66.

Kawai, K., Okamoto, H. and Imabayashi, H. 2009a. A fundamental study on range expansion of chironomids. - 67.

Lencioni, V. and Rossaro, B. 2009a. Chironomids of springs, rivers and lakes in five provinces and in the Beijing Municipality of the People's Republic of China. - 68.

Bernabò, P., Caputi, L., Frassanito, R., Guella, G., Jousson, O. and Lencioni, V. 2009a. Cold resistance in Pseudodiamesa branickii (Nowicki): physiological, molecular and biochemical aspects. - 69.

Majumdar, U. 2009a. Indian species of Glyptotendipes Kieffer (Diptera: Chironomidae) with a short account of some aspects of biology. - 70.

Makarchenko, E. A. 2009a. Pseudodiamesa nivosa (Goetghebuer, 1928) is not synonym of Pseudodiamesa arctica (Malloch, 1919) (Diptera: Chironomidae). - 71.

Marziali, L., Rossaro, B. and Lencioni, V. 2009a. Chironomid drift behavior (Insecta, Diptera) in an arctic stream (Svalbard Islands) under natural and induced light conditions. - 72-73. 
Wiedenbrug, S., Mendes, H. F. and TrivinhoStrixino, S. 2009a. New species of the genus Onconeura Andersen \& Sæther, 2005 (Diptera, Chironomidae) from Brazil. - 74.

Móra, A. 2009a. The diversity of chironomid assemblages of streams in Lake Balaton's catchment area. - 75.

Pinho, L. C. de and Froehlich, C. G. 2009a. Three new Neotropical species of Fissimentum Cranston et Nolte, 1996 (Diptera: Chironomidae: Chironominae). - 76.

Plank, A. 2009a. Chip - chironomid identification program: build your own determination key. 77-78.

Raposeiro, P., Costa, A. C. and Hughes, S. J. 2009a. Preliminary results of the use of chironomid pupal exuviae technique in oceanic islands: Azores Archipelago. - 79-80.

Sergeeva, I. V. 2009a. Fauna and ecology of the Russia Tanypodinae (Diptera, Chironomidae). $-81$.

Shimodoi, T., Kawai, K. and Imabayashi, H. 2009a. Fundamental study of fish effectiveness to control chironomid mass emergence. - 82.

Sonoda, K. C., Ortega, E., Vettorazzi, C. A. and Trivinho-Strixino, S. 2009a. Chironomidae assemblage from four Brazilian watersheds under different anthropogenic pressure. - 8384.

Tóth, M., Köműves, M. and Dévai, G. 2009a. Spatio-temporal distribution of phytaldwelling chironomid assemblages (Diptera: Chironomidae) in submerged vegetation of two Hungarian backwaters. - 85.

Watanabe, T., Kawai, K. and Imabayashi, H. 2009a. A fundamental study to control adult chironomid midges by using the light traps. 86.

Yan, C. and Wang, X. 2009a. A taxonomic discussion on a valid species of Harnischia longispuria Wang \& Zheng, 1993 (Diptera: Chironomidae). - 87.

Zinchenko, T. D. and Golovatyuk, L. V. 2009a. Responds of the river chironomid communities (inflows of the hypersaline lake Elton, the Low Volga, south of Russia) to high mineralization. - 88-89.

\section{$\underline{\text { C. Abstracts of Non-attending Colleagues }}$}

(Note: Several authors of contributions in paragraphs $\mathrm{A}$ and $\mathrm{B}$ did not attend the meeting either)

Chavan, R. J. 2009a. Diversity of chironomids (Diptera) in urban lakes at Aurangabad, India. $-91$.

Jacobsen, R. E. 2009b. Tanytarsus rexilius, new species, from oligotrophic marshes in the Florida Everglades. - 92.

Morozova, Y. Y. 2009a. Ecologicallymorphological analysis of Cryptochironomus Kieffer (Diptera: Chironomidae) species of the Volga River. - 93.

Zhang, E. 2009a. Fossil midges (Diptera: Chironomidae) as paleoecological indicators in Chinese lakes. - 94. 